
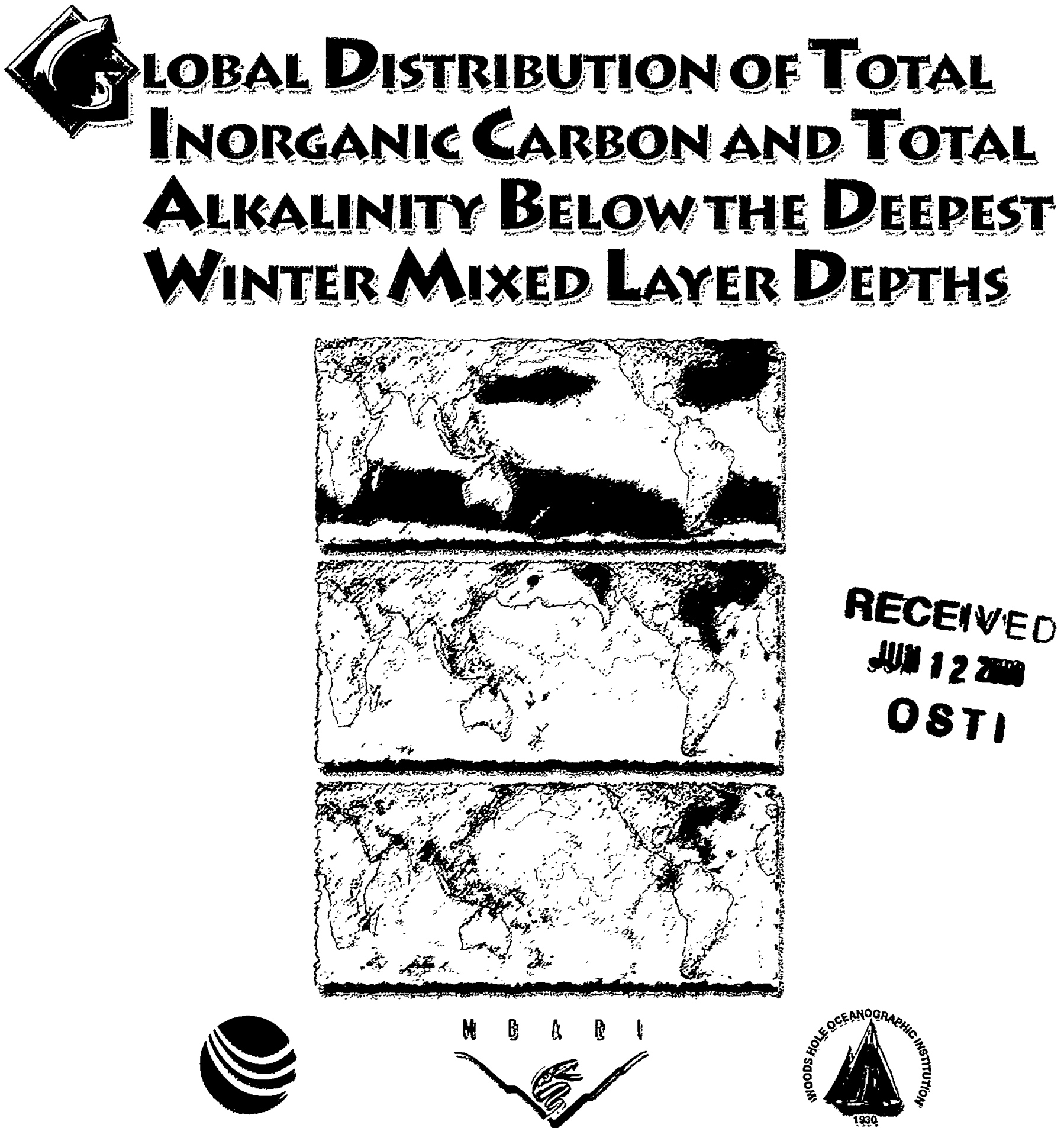

CARBON DIOXIDE INFORMATION ANALYSIS CENTER OAK RIDGE NATIONAL LABORATORY OAK RIDGE, TENNESSEE

Monterey Bay Aquarium Research Institute MOSS LANDING, CALIFORNIA

WoOdS Hole Oceanographic Institution WOOdS HOLE, MASSACHUSETTS 


\section{DOCUMENT AVAILABILITY}

Reports produced after January 1, 1996, are generally available free via the U.S. Department of Energy (DOE) Information Bridge.

Web site http://www.osti.gov/bridge

Reports produced before January 1,1996, may be purchased by members of the public from the following source.

National Technical Information Service

5285 Port Royal Road

Springfield, VA 22161

Telephone 703-605-6000 (1-800-553-6847)

TDD 703-487-4639

Fax 703-605-6900

E-mail info@ntis.fedworld.gov

Web site http://www.ntis.gov/support/ordernowabout.htm

Reports are available to DOE employees, DOE contractors, Energy Technology Data Exchange (ETDE) representatives, and International Nuclear Information System (INIS) representatives from the following source.

Office of Scientific and Technical Information

P.O. Box 62

Oak Ridge, TN 37831

Telephone 865-576-8401

Fax 865-576-5728

E-mail reports@adonis.osti.gov

Web site http://www.osti.gov/contact.html

This report was prepared as an account of work sponsored by an agency of the United States Government. Neither the United States Government nor any agency thereof, nor any of their employees, makes any warranty, express or implied, or assumes any legal liability or responsibility for the accuracy, completeness, or usefulness of any information, apparatus, product, or process disclosed, or represents that its use would not infringe privately owned rights. Reference herein to any specific commercial product, process, or service by trade name, trademark, manufacturer, or otherwise, does not necessarily constitute or imply its endorsement, recommendation, or favoring by the United States Government or any agency thereof. The views and opinions of authors expressed herein do not necessarily state or reflect those of the United States Government or any agency thereof. 


\section{DISCLAIMER}

Portions of this document may be illegible in electronic image products. Images are produced from the best available original document. 


\title{
GLOBAL DISTRIBUTION OF TOTAL INORGANIC CARBON AND TOTAL ALKALINITY BELOW THE DEEPEST WINTER MIXED LAYER DEPTHS
}

\author{
Contributed by \\ Catherine Goyet, ${ }^{1}$ Richard Healy, ${ }^{1}$ and \\ John Ryan ${ }^{2}$ \\ 'Woods Hole Oceanographic Institution \\ Woods Hole, Massachusetts \\ ${ }^{2}$ Monterey Bay Aquarium Research Institute \\ Moss Landing, California \\ Prepared by Alexander Kozyr ${ }^{3}$ \\ Carbon Dioxide Information Analysis Center \\ Oak Ridge National Laboratory \\ Oak Ridge, Tennessee \\ ${ }^{3}$ Energy, Environment, and Resources Center \\ The University of Tennessee \\ Knoxville, Tennessee \\ Environmental Sciences Division \\ Publication No. 4995
}

Date Published: May 2000

Prepared for the

Environmental Sciences Division

Office of Biological and Environmental Research

U.S. Department of Energy

Budget Activity Numbers KP 1204010 and KP 1202030

Prepared by the

Carbon Dioxide Information Analysis Center

OAK RIGE NATIONAL LABORATORY

Oak Ridge, Tennessee 37831-6335

managed by

UT-BATTELLE, LLC

for the

U.S. DEPARTMENT OF ENERGY

under contract DE-AC05-00OR22725 


\section{CONTENTS}

Page

LIST OF FIGURES $\ldots \ldots \ldots \ldots \ldots \ldots \ldots \ldots \ldots \ldots \ldots \ldots \ldots \ldots \ldots \ldots \ldots$

LIST OF TABLES $\ldots \ldots \ldots \ldots \ldots \ldots \ldots \ldots \ldots \ldots \ldots \ldots \ldots \ldots \ldots \ldots$ vii

ACKNOWLEDGMENTS $\ldots \ldots \ldots \ldots \ldots \ldots \ldots \ldots \ldots \ldots \ldots \ldots \ldots \ldots \ldots$ ix

ABSTRACT $\ldots \ldots \ldots \ldots \ldots \ldots \ldots \ldots \ldots \ldots \ldots \ldots \ldots \ldots \ldots \ldots \ldots \ldots \ldots$

PART 1: OVERVIEW $\ldots \ldots \ldots \ldots \ldots \ldots \ldots \ldots \ldots \ldots \ldots \ldots \ldots \ldots \ldots \ldots$

1. INTRODUCTION $\ldots \ldots \ldots \ldots \ldots \ldots \ldots \ldots \ldots \ldots \ldots \ldots \ldots \ldots \ldots \ldots$

2. DATA SETS AND METHODS $\ldots \ldots \ldots \ldots \ldots \ldots \ldots \ldots \ldots \ldots \ldots \ldots \ldots$

2.1 Determination of Monthly Mixed Layer Depth Fields .............. 4

2.2 Interpolation of TALK Below the Deepest Mixed Layer $\ldots \ldots \ldots \ldots \ldots \ldots$

2.3 Interpolation of $\mathrm{TCO}_{2}$ Below the Deepest Mixed Layer $\ldots \ldots \ldots \ldots \ldots$

3. RESULTS $\ldots \ldots \ldots \ldots \ldots \ldots \ldots \ldots \ldots \ldots \ldots \ldots \ldots \ldots \ldots \ldots \ldots \ldots \ldots \ldots$

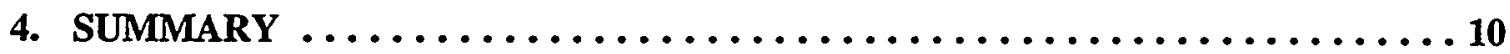

5. HOW TO OBTAIN THE DATA AND DOCUMENTATION $\ldots \ldots \ldots \ldots \ldots \ldots$

6. REFERENCES $\ldots \ldots \ldots \ldots \ldots \ldots \ldots \ldots \ldots \ldots \ldots \ldots \ldots \ldots \ldots \ldots \ldots \ldots \ldots$

PART 2: CONTENT AND FORMAT OF DATA FILES $\ldots \ldots \ldots \ldots \ldots \ldots \ldots \ldots$

7. FILE DESCRIPTIONS $\ldots \ldots \ldots \ldots \ldots \ldots \ldots \ldots \ldots \ldots \ldots \ldots \ldots \ldots \ldots$

7.1 ndp076.txt (File 1) $\ldots \ldots \ldots \ldots \ldots \ldots \ldots \ldots \ldots \ldots \ldots \ldots \ldots \ldots \ldots \ldots \ldots$

7.2 coef_talk.for (File 2$) \ldots \ldots \ldots \ldots \ldots \ldots \ldots \ldots \ldots \ldots \ldots \ldots$

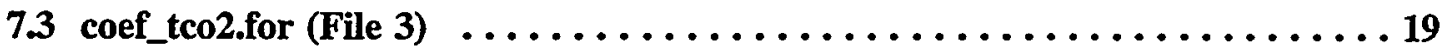

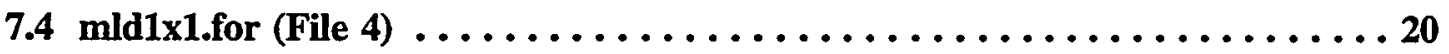

7.5 talkdatfor (File 5) $\ldots \ldots \ldots \ldots \ldots \ldots \ldots \ldots \ldots \ldots \ldots \ldots \ldots \ldots \ldots \ldots$ 


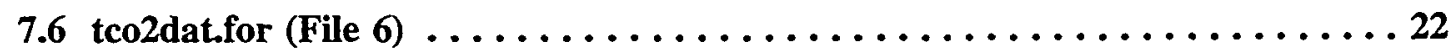

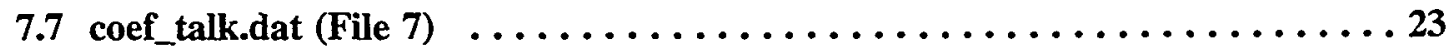

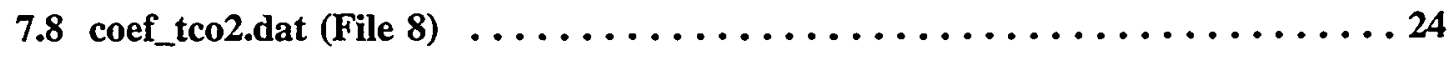

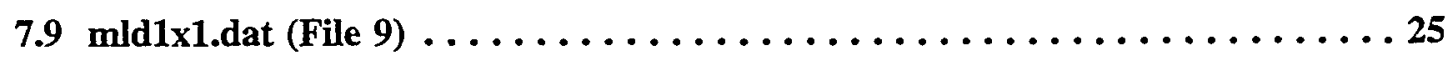

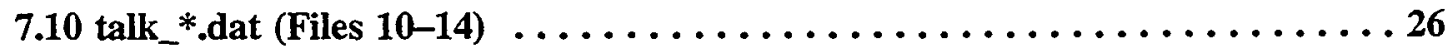

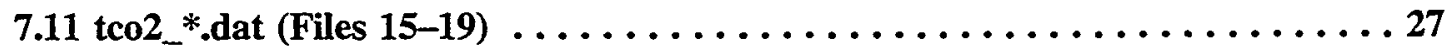




\section{LIST OF FIGURES}

Figure

Page

1 Spatial distribution of the maximum depth $(\mathrm{m})$ of the mixed layer. $\ldots \ldots \ldots 7$

2 Spatial distribution of the annual mean $\mathrm{TCO}_{2}(\mu \mathrm{mol} / \mathrm{kg})$ at $500 \mathrm{~m}$ (top), $1500 \mathrm{~m}$ (middle), and $3500 \mathrm{~m}$ (bottom) $\ldots \ldots \ldots \ldots \ldots \ldots$

3 Spatial distribution of the annual mean TALK ( $\mu \mathrm{mol} / \mathrm{kg}$ ) at $500 \mathrm{~m}$ (top), $1500 \mathrm{~m}$ (middle), and $3500 \mathrm{~m}$ (bottom) $\ldots \ldots \ldots \ldots \ldots \ldots$ 



\section{LIST OF TABLES}

$\begin{array}{lll}\text { Table } & \text { Page }\end{array}$

1 Summary of data sets used for interpolation of the $\mathrm{TCO}_{2}$ and TALK fields on the global scale $\ldots \ldots \ldots \ldots \ldots \ldots \ldots \ldots \ldots \ldots \ldots \ldots$

2 Content, size, and format of data files $\ldots \ldots \ldots \ldots \ldots \ldots \ldots \ldots \ldots$ 



\section{ACKNOWLEDGEMENTS}

The authors would like to thank all oceanographers who went to sea, performed the measurements, and were responsible for the measurements of $\mathrm{CO}_{2}$ and hydrographic parameters. The authors also thank G. Monterey of Pacific Fisheries Environmental Laboratory, Pacific Grove, California, for MLD calculations at NODC. They thank the funding agencies: National Science Foundation, U.S. Department of Energy, NASA, and NOAA, for supporting the seagoing programs. This work was supported by NASA through Grant NAGW-2324. 


\begin{abstract}
Goyet, C., R. J. Healy, and J. P. Ryan. 2000. Global distribution of total inorganic carbon and total alkalinity below the deepest winter mixed layer depths. ORNL/CDIAC-127, NDP-076. Carbon Dioxide Information Analysis Center, Oak Ridge National Laboratory, U.S. Department of Energy, Oak Ridge, Tennessee, U.S.A. 40 pp.

Modeling the global ocean-atmosphere carbon dioxide system is becoming increasingly important to greenhouse gas policy. These models require initialization with realistic threedimensional (3-D) oceanic carbon fields. This report presents an approach to establishing these initial conditions from an extensive global database of ocean carbon dioxide $\left(\mathrm{CO}_{2}\right)$ system measurements and well-developed interpolation methods. These methods are limited to waters below the deepest mixed layer. The data used for these interpolations include the recent high-quality data sets from the World Ocean Circulation Experiment (WOCE), Joint Global Ocean Flux Study (JGOFS), and Ocean-Atmosphere Carbon Exchange Study (OACES) programs. Prior to analysis, all carbon data were adjusted to established reference material listed in http://www-mpl.ucsd.edu/people/adickson/CO2_QC/. The interpolation methodology employs correlation between $\mathrm{CO}_{2}$ system properties and other more widely measured properties: potential temperature, salinity, and apparent oxygen utilization. The correlations are computed for each profile, and the coefficients are interpolated to the $1^{\circ} \times 1^{\circ} \times 32$ vertical-layer grid at a monthly temporal resolution. Finally, the gridded coefficients are applied to a global monthly climatology of ocean temperature, salinity, and oxygen to compute total $\mathrm{CO}_{2}\left(\mathrm{TCO}_{2}\right)$ and total alkalinity (TALK) for the 3-D grid.

This approach offers advantages over spin up of a single profile in defining spatial variation in $\mathrm{CO}_{2}$ system properties because it reduces initialization time and provides a more accurate carbon field. The results provide an unprecedented "view" of the global distribution of TALK and $\mathrm{TCO}_{2}$ in the ocean. These results as well as those from the monthly mixed layer depths can be used in diagnostic and prognostic global ocean models.

The data set of the gridded climatological fields of $\mathrm{TCO}_{2}, \mathrm{TALK}$, and mixed layer depths is available free of charge as a numeric data package from the Carbon Dioxide Information Analysis Center (CDIAC; http://cdiac.esd.ornl.gov/). The interpolated data set includes seasonal $\mathrm{TCO}_{2}$ and TALK fields as well as the coefficients used to estimate these concentrations and the monthly mixed layer depths.
\end{abstract}

Keywords: Total carbon dioxide, total alkalinity, mixed layer depth, carbon fields, inorganic carbon, global ocean 
PART 1: OVERVIEW 


\section{INTRODUCTION}

One of the main objectives of the study of the oceanic carbon cycle is to quantify the present and future role of the ocean in the absorption of anthropogenic carbon dioxide $\left(\mathrm{CO}_{2}\right)$. In situ data are typically used to quantify the present anthropogenic $\mathrm{CO}_{2}$ concentrations in the ocean (Brewer 1978; Chen and Millero 1979; Chen 1993; Wallace 1995; Gruber et al. 1996; Gruber 1998; Peng et al. 1998; Sabine et al. 1999; Goyet et al. 1999). Global ocean models are mainly used in a prognostic mode to estimate the future penetration of anthropogenic $\mathrm{CO}_{2}$ on the global scale (Sarmiento et al. 1992; Bhaskaran et al. 1995; Washington and Meehl 1996). Yet, accurate global initialization fields of the $\mathrm{CO}_{2}$ properties in seawater, such as total $\mathrm{CO}_{2}\left(\mathrm{TCO}_{2}\right)$ and total alkalinity (TALK), do not exist.

In order to study the oceanic carbon cycle and to accurately describe and quantify the $\mathrm{TCO}_{2}$ and TALK fields on the global scale, $\mathrm{TCO}_{2}$ and TALK were measured with high accuracy throughout the water column of the major oceans. These measurements were mainly performed over the last two decades during intensive national and international field programs. Most of the data of these field programs are now freely available to the scientific community. However, these data need to be interpolated on a regular grid before they can easily be used in global ocean models.

The purpose of this work is therefore to best interpolate these data on a regular grid for use in ocean models. The interpolation is based on each measured profile from the base of the mixed layer to the bottom of the ocean. The data within the mixed layer are not considered here because they are subject to large spatial and monthly variations that are still difficult to accurately quantify. The variations of the $\mathrm{CO}_{2}$ properties in the mixed layer are controlled by ocean circulation, evaporation/precipitation, dissolution of calcium carbonate, photosynthesis

and oxidation of organic matter, and $\mathrm{CO}_{2}$ flux across the ocean-atmosphere interface including penetration of anthropogenic $\mathrm{CO}_{2}$. Many independent studies are currently designed to best quantify and parameterize each of these processes and the overall variations of the $\mathrm{CO}_{2}$ properties in the mixed layer (Takahashi et al. 1997; Millero et al. 1998).

Below the mixed layer, $\mathrm{TCO}_{2}$ and TALK are controlled by ocean mixing, formation/dissolution of calcium carbonate, and oxidation of organic matter (Brewer 1978). In other words, short-timescale processes do not significantly affect $\mathrm{TCO}_{2}$ and TALK below the mixed layer. Thus it is possible to interpolate the data measured below the mixed layer at different times of year to acquire a reasonable understanding of the $\mathrm{TCO}_{2}$ and TALK fields. In ocean areas where anthropogenic $\mathrm{CO}_{2}$ is present (mainly in the upper $2000 \mathrm{~m}$ ), it is also necessary to specify if and how data from different years are adjusted to a specific year before interpolation.

In practice, the distribution of anthropogenic $\mathrm{CO}_{2}$ concentrations in the ocean is not accurately known. Estimates can differ significantly (Coatanoan et al. 2000) according to the various assumptions used. Until these differences are understood and considerably reduced, it will be very difficult to estimate pre-anthropogenic $\mathrm{TCO}_{2}$ fields on the global scale. Consequently, in this paper authors interpolate the measured $\mathrm{TCO}_{2}$ and TALK data without adjustment for the variations in anthropogenic $\mathrm{CO}_{2}$ concentration for a given year. Because most of the data were measured within the past twenty years, such small adjustment to the different data sets (except for the North Atlantic Ocean) would mainly be within the uncertainty of the interpolated field. The results provide an estimate of these fields for the mid-1990s, when most of the accurate measurements were performed. 


\section{DATA SETS AND METHODS}

In order to interpolate the measured $\mathrm{TCO}_{2}$ and TALK data, the available observations were assembled (Table 1). Measurements prior to 1990 did not use the accurate standards established by Dickson (1997) for calibrating $\mathrm{TCO}_{2}$. Therefore pre-1990 profiles were adjusted by comparing deep measurements within $1^{\circ}$ of latitude and longitude, as described for the Atlantic Ocean (Goyet et al. 1997), the Pacific Ocean (Feely et al. 1998), and the Indian Ocean (Sabine et al. 1999).

All the TALK measurements were performed by potentiometry (Dyrssen 1965; Millero et al. 1998). Most of the $\mathrm{TCO}_{2}$ measurements were performed by extraction/coulometry (Johnson et al. 1985, 1987, 1993, 1998) except for the cruises prior to 1990 where $\mathrm{TCO}_{2}$ was measured by potentiometry. All these measurements are described in detail in the Handbook of Methods for the Analysis of the Various Parameters of the Carbon Dioxide System in Sea Water (DOE 1994).

Table 1. Summary of data sets used for interpolation of the $\mathrm{TCO}_{2}$ and TALK fields on the global scale

\begin{tabular}{|c|c|}
\hline Field program & Reference \\
\hline GEOSECS $^{1}$ & Takahashi et al. 1980 \\
\hline INDIGO $^{2}$ & Poisson et al. 1988, 1989, 1990 \\
\hline JGOFS $^{3}$ & http://www1.whoi.edu/jgofs.html \\
\hline OACES $^{4}$ & NOAA $^{8}$; http://www.aoml.noaa.gov/ocd/oaces \\
\hline TTO $^{5}$ & Data reports, TTO 1986a,b \\
\hline WOCE $^{6}$ SAVE $^{7}$ & CDIAC; http://cdiac.esd.ornl.gov/oceans/home.html \\
\hline
\end{tabular}

'Geochemical Ocean Sections

${ }^{2}$ Indian Ocean Global Observation

${ }^{3}$ Joint Global Ocean Flux Study

${ }^{4}$ Ocean-Atmosphere Carbon Exchange Study

${ }^{5}$ Transient Tracers in the Ocean

${ }^{6}$ World Ocean Circulation Experiment

${ }^{7}$ South Atlantic Ventilation Experiment

${ }^{8}$ National Oceanographic and Atmospheric Administration

\subsection{Determination of Monthly Mixed Layer Depth Fields}

In order to define monthly mixed layer depth (MLD), a weighted average based on two sources of MLD information was created, one source based on observations and the other based on a numerical ocean model. The first was the MLD product offered by the National Ocean Data Center (NODC). Specifically, the MLD fields computed via potential density at $1^{\circ} \times 1^{\circ}$ from gridded temperature/salinity (T/S) (Levitus and Boyer 1994a; Levitus et al. 1994) were used. This product is available at http://www.cdc.noaa.gov/cdc/data.nodc.woa94.html. The second source was Fleet Numerical Meteorology and Oceanography Center (FNMOC) 
model mixed layer output at a resolution of $2.5^{\circ} \times 2.5^{\circ}$ (Clancy and Sadler 1992). Using daily FNMOC fields from March through December 1995 and January and February, 1996, monthly means were computed and then gridded to the same resolution as the NODC fields.

The T/S observations required for the NODC MLD product are highly non-uniformly distributed over the globe, and much of the ocean is completely unsampled (see Levitus and Boyer 1994a for methodology of filling the global $1^{\circ} \times 1^{\circ}$ grid). As a result, the MLD fields contain unrealistic spatial distributions, horizontal gradients, and magnitudes. This problem with definition of MLD from gridded T/S is known, and a developing approach is to define MLD from individual hydrographic profiles and to grid resultant MLD estimates only where observations exist (Monterey, G., Pacific Fisheries Environmental Laboratory, Pacific Grove, Calif., personal communication.). However, such MLD fields are not currently available. Therefore, a weighting function for the NODC MLD fields was defined based on observation density. Specifically, we used the monthly average number of salinity observations at NODC levels within the upper $50 \mathrm{~m}$. Based on mapped observation density, a cutoff of 75 was chosen to define where salinity was well sampled and thus where the NODC MLD fields had a sufficient observational base. Above this cutoff, the weighting for NODC MLD was 1 ( $7 \%$ of the grid points). Below the cutoff, the weighting for NODC MLD was the average number of observations divided by 75 . Lastly, because some NODC MLD values are extremely and unrealistically deep where few observations exist, zero weighting was assigned where NODC MLD was $>400 \mathrm{~m}$. This weighting procedure retained NODC MLD estimates in relatively well-observed regions and relied on the model (FNMOC) MLD estimates for poorly observed regions (in proportion to the paucity of observations).

Following this definition of the weighted average MLD product, there still remained grid points where neither input data set provided information. Missing grid points within the latitude range $65^{\circ} \mathrm{N}$ to $65^{\circ} \mathrm{S}$ were filled with a combination of spatial and temporal averaging ( \pm 2 months and $5^{\circ}$ of latitude/longitude). Any points not filled by this procedure were filled with the mean of all valid monthly MLD values for that grid point. Finally, a $5^{\circ} \times 5^{\circ}$ median filter was applied to the monthly MLD fields to smooth the boundaries where missing data were filled in the last step.

\subsection{Interpolation of TALK Below the Deepest Mixed Layer}

Below the mixed layer, TALK can be interpolated by piecewise linear regression as a function of potential temperature $(\theta)$ and salinity $(S)$ :

$$
\text { TALK }=a+b \theta+c S
$$

One regression was performed in each of the two layers: from the wintertime mixed layer down to $1000 \mathrm{~m}$, and below $1000 \mathrm{~m}$. The cutoff at $1000 \mathrm{~m}$ reflects the mean depth of the TALK maximum. The coefficients were calculated for each profile, interpolated to the 3-D grid using the Generic Mapping Tools (GMT) software (Wessel and Smith 1995), and applied to climatological temperature and salinity (Levitus and Boyer 1994a,b; Levitus et al. 1994) to compute TALK. Uncertainty associated with this interpolation procedure in the Indian, Pacific, and Atlantic Oceans is respectively estimated to be $\pm 8.4 \mu \mathrm{mol} / \mathrm{kg}, \pm 10.2 \mu \mathrm{mol} / \mathrm{kg}$, and $\pm 4.6 \mu \mathrm{mol} / \mathrm{kg}$ in the upper $1000 \mathrm{~m}$, and $\pm 4.8 \mu \mathrm{mol} / \mathrm{kg}, \pm 9.1 \mu \mathrm{mol} / \mathrm{kg}$, and $\pm 5.9 \mu \mathrm{mol} / \mathrm{kg}$ at depths below $1000 \mathrm{~m}$. The mean uncertainty associated with the TALK interpolation procedure in the global ocean below the mixed layer is estimated to be $\pm 5.5 \mu \mathrm{mol} / \mathrm{kg}$. 


\subsection{Interpolation of $\mathrm{TCO}_{2}$ Below the Deepest Mixed Layer}

As shown earlier (Goyet and Davis 1997), below the winter mixed layer, $\mathrm{TCO}_{2}$ can be interpolated as a function of potential temperature $(\theta)$, apparent oxygen utilization (AOU), and salinity (S):

$$
\mathrm{TCO}_{2}=\mathrm{a}+\mathrm{b} \theta+\mathrm{cAOU}+\mathrm{dS}
$$

The coefficients were calculated for each profile, interpolated to the 3-D grid using the GMT software, and applied to climatological hydrographic properties to compute $\mathrm{TCO}_{2}$ at the grid points below the deepest winter mixed layer depth. Uncertainty associated with this interpolation procedure in the Indian, Pacific, and Atlantic Oceans is respectively estimated to be $\pm 7.9 \mu \mathrm{mol} / \mathrm{kg}, \pm 14.5 \mu \mathrm{mol} / \mathrm{kg}$, and $\pm 8.1 \mu \mathrm{mol} / \mathrm{kg}$. The mean uncertainty associated with the $\mathrm{TCO}_{2}$ interpolation procedure in the global ocean below the mixed layer is estimated to be $\pm 9.4 \mu \mathrm{mol} / \mathrm{kg}$. The uncertainty is the largest in the Pacific Ocean and reflects the relatively poor data density in this large ocean.

\section{RESULTS}

The results of this work are monthly global fields of $\mathrm{TCO}_{2}$ and TALK, the coefficients used to compute these $\mathrm{CO}_{2}$ system properties, and the maximum mixed layer depths used to define the shallowest depth for these computations. Figure 1 shows the geographical distribution of the maximum depth of the mixed layer. The deepest mixed layers are observed in the northern Atlantic Ocean. The Southern Ocean south of $50^{\circ} \mathrm{S}$ is a large area with deep mixed layers as a result of the strong atmospheric forcing. The shallowest $(<20 \mathrm{~m})$ mixed layers are observed at low latitudes.

Figures 2 and 3 illustrate the annual mean concentrations of $\mathrm{TCO}_{2}$ and TALK, respectively, at $500 \mathrm{~m}, 1500 \mathrm{~m}$, and $3500 \mathrm{~m}$ between $60^{\circ} \mathrm{N}$ and $60^{\circ} \mathrm{S}$. These maps clearly show the differences between the three major oceans. In the Pacific Ocean, $\mathrm{TCO}_{2}$ concentrations are generally higher on the eastern side than on the western side (Fig. 2). At $500 \mathrm{~m}, \mathrm{TCO}_{2}$ concentrations have the signature of the upper layers and reflect the circulation patterns. The equatorial upwelling is particularly evident with $\mathrm{TCO}_{2}$ concentrations higher on the eastern side than the western side.

At $1500 \mathrm{~m}$, the highest concentrations are observed in the Pacific Ocean north of $35^{\circ} \mathrm{N}$, while the lowest concentrations are observed in the Atlantic Ocean north of $35^{\circ} \mathrm{N}$. At $3500 \mathrm{~m}$, $\mathrm{TCO}_{2}$ concentrations in the Indian Ocean are comparable to those in the Pacific Ocean at similar latitudes. The lowest $\mathrm{TCO}_{2}$ concentrations are observed in the northwestern Atlantic Ocean. At $3500 \mathrm{~m}, \mathrm{TCO}_{2}$ concentrations typically differ by $200 \mu \mathrm{mol} / \mathrm{kg}$ or more between the different ocean basins of the Northern Hemisphere. In contrast, in the Southern Hemisphere south of $40^{\circ} \mathrm{S}$, the variation of $\mathrm{TCO}_{2}$ concentration between oceans is typically less than $50 \mu \mathrm{mol} / \mathrm{kg}$.

At $500 \mathrm{~m}$, TALK is lowest in the Pacific Ocean. However, at 1500 and $3500 \mathrm{~m}$, TALK is lowest in the Atlantic Ocean. In contrast to $\mathrm{TCO}_{2}$, the highest TALK concentrations are in the northern Indian Ocean. 


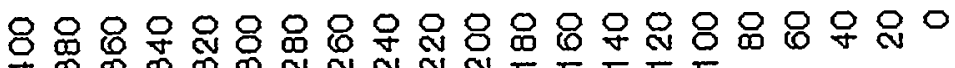
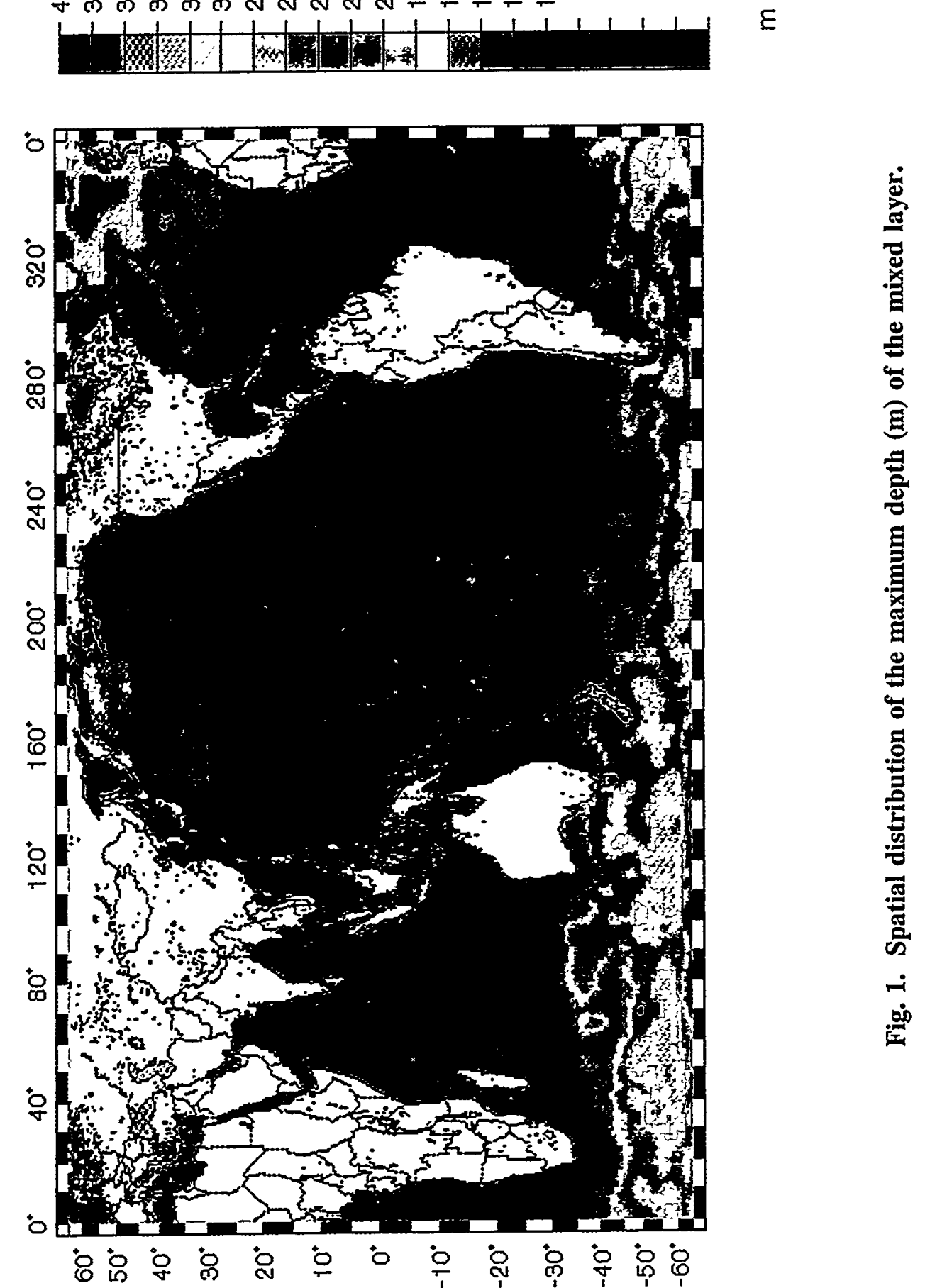

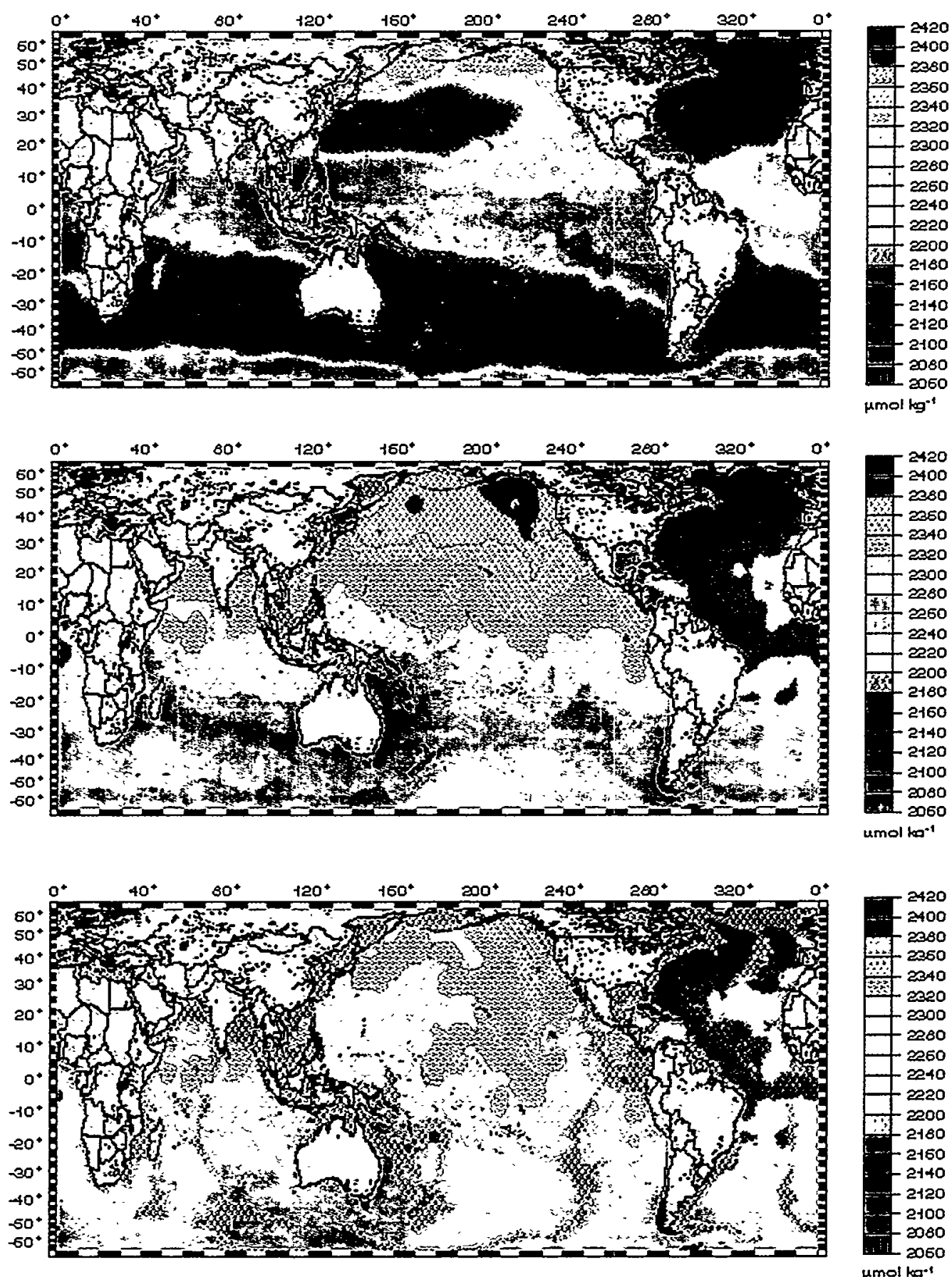

Fig. 2. Spatial distribution of the annual mean $\mathrm{TCO}_{2}(\mu \mathrm{mol} / \mathrm{kg})$ at $500 \mathrm{~m}$ (top), $1500 \mathrm{~m}$ (middle), and $3500 \mathrm{~m}$ (bottom). 

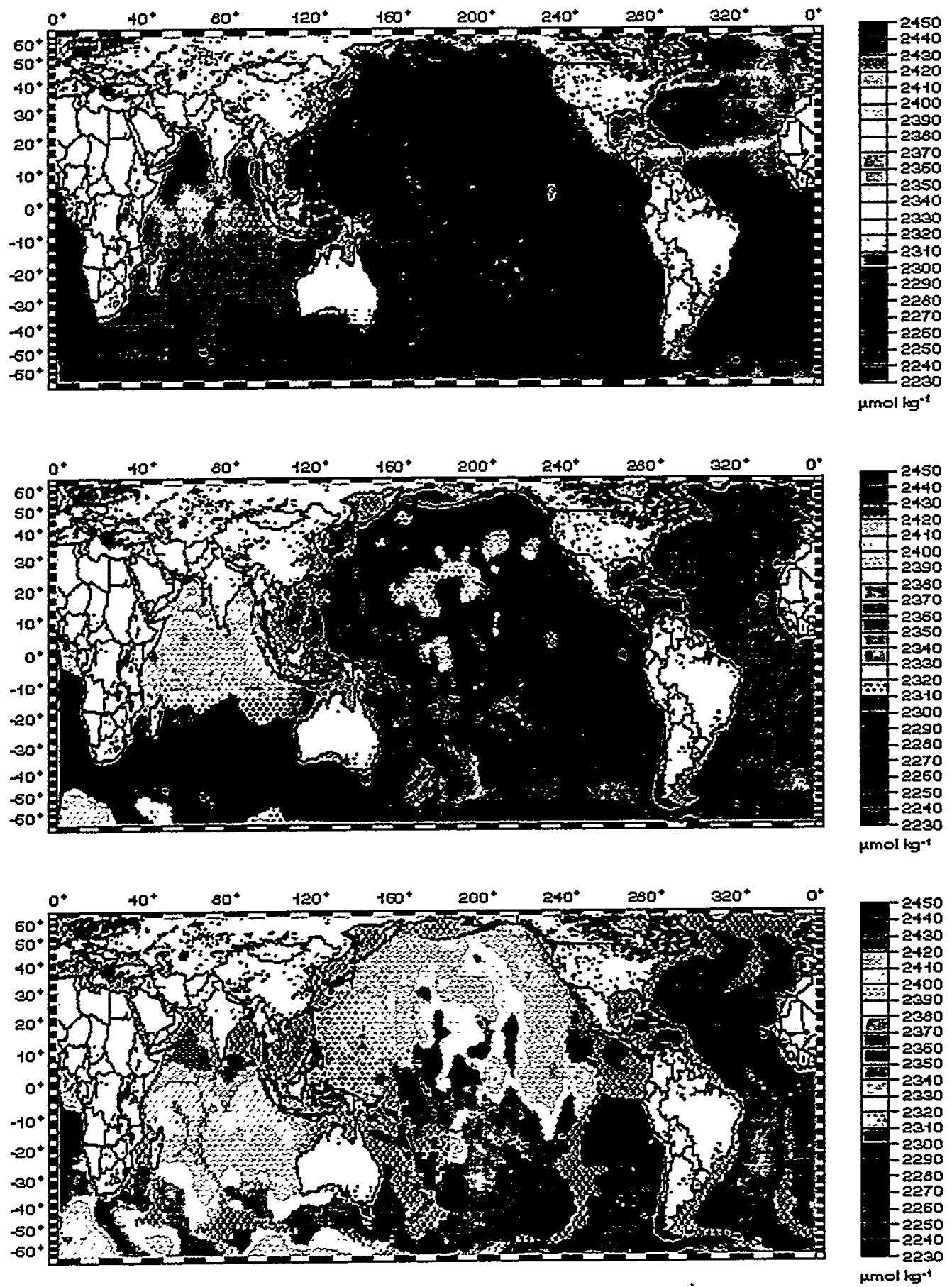

Fig. 3. Spatial distribution of the annual mean TALK $(\mu \mathrm{mol} / \mathrm{kg})$ at $500 \mathrm{~m}$ (top), $1500 \mathrm{~m}$ (middle), and $3500 \mathrm{~m}$ (bottom). 
Overall, the distribution of $\mathrm{TCO}_{2}$ and TALK in seawater reflects the circulation of the different water masses. Briefly, in the North Atlantic Ocean the waters are young and the concentration of $\mathrm{TCO}_{2}$ is relatively low, whereas the concentration of TALK is relatively high. However, because it is a location of deep water formation, the $\mathrm{TCO}_{2}$ gradient from the surface to the bottom is relatively small, and anthropogenic $\mathrm{CO}_{2}$ penetrates to the bottom (Chen 1993). From the North Atlantic Ocean the water flows to the South Atlantic Ocean and to the Southern Ocean before going into the North Indian and North Pacific Oceans, where $\mathrm{TCO}_{2}$ concentrations are the highest.

\section{SUMMARY}

Understanding the complex, interacting processes that determine global ocean uptake of atmospheric $\mathrm{CO}_{2}$ requires accurate definition of initial conditions and accurate representation of the processes forcing variation. An approach to defining global, monthly 3-D fields of $\mathrm{TCO}_{2}$ and TALK below the deepest mixed layer was presented in this report. These fields are now available to the scientific community through CDIAC. The accuracy of these interpolated fields is the best available today given the in situ data fields. They accurately reflect the main characteristics of global water mass circulation. This approach offers advantages over spin up of a single profile in defining spatial variation in $\mathrm{CO}_{2}$ system properties because it provides a more accurate carbon field and reduces initialization time. As additional data become available, it will be possible to increase the accuracy of mixed layer depths, $\mathrm{TCO}_{2}$, and TALK fields. 


\section{HOW TO OBTAIN THE DATA AND DOCUMENTATION}

This database (NDP-076) is available free of charge from CDIAC. The data are available from CDIAC's anonymous file transfer protocol (FTP) area via the Internet. Please note: Your computer needs to have FTP software loaded on it (this is built in to most newer operating systems). Use the following commands to obtain the database.

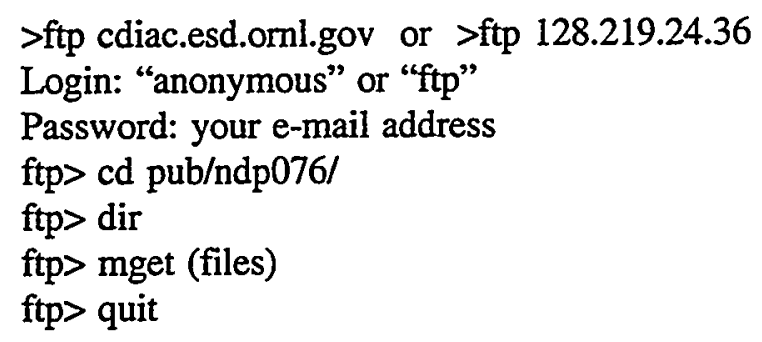

The complete documentation and data can also be obtained from the CDIAC oceanographic Web site (http://cdiac.esd.oml.gov/oceans/doc.html), through CDIAC's online ordering system (http://cdiac.esd.ornl.gov/pns/how_order.html), or by contacting CDIAC.

Contact information:

Carbon Dioxide Information Analysis Center

Oak Ridge National Laboratory

P.O. Box 2008

Oak Ridge, Tennessee 37831-6335

U.S.A.

Telephone: 865-574-3645

Telefax: 865-574-2232

E-mail: cdiac@ornl.gov

Internet: http://cdiac.esd.ornl.gov/ 


\section{REFERENCES}

Bhaskaran, B., J. F. B. Mitchell, J. Lavery, and M. Lal. 1995. Climatic response of Indian subcontinent to doubled $\mathrm{CO}_{2}$ concentration. International Journal of Climatology $15: 873-92$.

Brewer, P. G. 1978. Direct observation of the oceanic $\mathrm{CO}_{2}$ increase. Geophysical Research Letters 5:997-1000.

Chen, C.-T. 1993. The oceanic anthropogenic $\mathrm{CO}_{2}$ sink. Chemosphere 27:1041-64.

Chen, C.-T., and F. J. Millero. 1979. Gradual increase of oceanic $\mathrm{CO}_{2}$. Nature 277:205-6.

Clancy, R. M., and W. D. Sadler. 1992. The Fleet Numerical Meteorology and Oceanography Center suite of oceanographic models and products. Weather and Forecasting 7:307-27.

Coatanoan C., C. Goyet, N. Gruber, C. L. Sabine, and M. Warner. 2000. Comparison of the two approaches to quantify anthropogenic $\mathrm{CO}_{2}$ in the ocean: Results from the northern Indian Ocean. Global Biogeochemical Cycle (in press).

Dickson, A. G. 1997. Reference material batch information. http://www-mpl.ucsd.edu/people/adickson/CO2_QC/level1/Batches.html

DOE (U.S. Department of Energy). 1994. Handbook of methods for analysis of the various parameters of the carbon dioxide system in seawater: Version 2. ORNL/CDIAC-74. A. G. Dickson and C. Goyet (eds.). Carbon Dioxide Information Analysis Center, Oak Ridge National Laboratory, Oak Ridge, Tenn.

Dyrssen, D. 1965. A Gran titration of sea water on board Sagitta. Acta Chemica Scandinavica 19(5):1265.

Feely, R. A., M. F. Lamb, D. J. Greeley, and R. Wanninkhof. 1999. Comparison of the carbon system parameters at the global $\mathrm{CO}_{2}$ survey crossover locations in the North and South Pacific Ocean, 1990-1996. ORNL/CDIAC-115. Carbon Dioxide Information Analysis Center, Oak Ridge National Laboratory, U.S. Department of Energy, Oak Ridge, Tennessee, U.S.A.

Goyet C., and D. Davis. 1997. Estimation of total $\mathrm{CO}_{2}$ concentration throughout the water column. Deep-Sea Research I 44(5):859-77.

Goyet, C., C. Coatanoan, G. Eischeid, T. Amaoka, K. Okuda, R. Healy, and S. Tsunogai. 1999. Spatial variation of total $\mathrm{CO}_{2}$ and total alkalinity in the northern Indian Ocean: A novel approach for the quantification of anthropogenic $\mathrm{CO}_{2}$ in seawater. Journal of Marine Research 57:135-63. 
Goyet, C., R. Healy, S. J. McCue, and D. M. Glover. 1997. Interpolation of $\mathrm{TCO}_{2}$ data on a $1^{\circ} \times 1^{\circ}$ grid throughout the water column below $500 \mathrm{~m}$ depth in the Atlantic Ocean.

Deep-Sea Research I 44(12):1945-55.

Gruber, N. 1998. Anthropogenic $\mathrm{CO}_{2}$ in the Atlantic Ocean. Global Biogeochemical Cycles 12(1):165-91.

Johnson, K. M., A. E. King, and J. M. Sieburth. 1985. Coulometric $\mathrm{TCO}_{2}$ analyses for marine studies: An introduction. Marine Chemistry 16:61-82.

Johnson, K. M., J. M. Sieburth, P. J. L. Williams, and L. Brandstrom. 1987. Coulometric total carbon dioxide analysis for marine studies: Automation and calibration. Marine Chemistry 21:117-33.

Johnson, K. M., K. D. Wills, D. B. Butler, W. K. Johnson, and C. S. Wong. 1993. Coulometric total carbon dioxide analysis for marine studies: Maximizing the performance of an automated continuous gas extraction system and coulometric detector. Marine Chemistry 44:167-87.

Johnson, K. M., A. G. Dickson, G. Eischeid, C. Goyet, P. Guenther, F. J. Millero, D. Purkerson, C. L. Sabine, R. G. Schottle, D. R. W. Wallace, R. J. Wilke, and C. D. Winn. 1998. Coulometric total carbon dioxide analysis for marine studies: Assessment of the quality of total inorganic carbon measurements made during the U.S. Indian Ocean $\mathrm{CO}_{2}$ 1994-1996. Marine Chemistry 63:21-37.

Levitus, S., and T. P. Boyer. 1994a. World Ocean Atlas (1994). Vol. 4: Temperature. NOAA Atlas NESDIS 4, National Oceanic and Atmospheric Administration, U.S. Department of Commerce, Washington, D.C.

Levitus, S., and T. P. Boyer. 1994b. World Ocean Atlas (1994). Vol. 2: Oxygen. NOAA Atlas NESDIS 2, National Oceanic and Atmospheric Administration, U.S. Department of Commerce, Washington, D.C.

Levitus, S., R. Burgett, and T. P. Boyer. 1994. World Ocean Atlas (1994). Vol. 3: Salinity. NOAA Atlas NESDIS 3, National Oceanic and Atmospheric Administration, U.S. Department of Commerce, Washington, D.C.

Millero, F. J., K. Lee, and M. Roche. 1998. Distribution of alkalinity in the surface waters of the major oceans. Marine Chemistry 60:111-30.

Peng, T.-H., R. Wanninkhof, J. L. Bullister, R. A. Feely, and T. Takahashi. 1998. Quantification of decadal anthropogenic $\mathrm{CO}_{2}$ uptake in the ocean based on dissolved inorganic carbon measurements. Nature 396:560-63.

Poisson, A., B. Schauer, and C. Brunet. 1988. Les rapports des campagnes à la mer à bord du Marion Dufresne. MD 43/INDIGO 1. No. 85-06. In Les publications de la mission de recherche des Terres Australes et Antarctiques Françaises. Paris, France. 
Poisson, A., B. Schauer, and C. Brunet. 1989. Les rapports des campagnes à la mer à bord du Marion Dufresne. MD 49/INDIGO 2. No. 86-03. In Les publications de la mission de recherche des Terres Australes et Antarctiques Françaises. Paris, France.

Poisson, A., B. Schauer, and C. Brunet. 1990. Les rapports des campagnes à la mer à bord du Marion Dufresne. MD 53/INDIGO 3. No. 87-02. In Les publications de la mission de recherche des Terres Australes et Antarctiques Françaises. Paris, France.

Takahashi, T., W. S. Broecker, A. E. Brainbridge, and R. F. Weiss. 1980. Carbonate chemistry of the Atlantic, Pacific, and Indian Oceans: The results of the GEOSECS Expeditions, 1972-1978. Technical Report, 1, CU-1-80. Lamont-Doherty Geological Observatory, Palisades, N.Y.

Takahashi, T., R. A. Feely, R. F. Weiss, R. H. Wanninkhof, D. W. Chipman, and S. C. Sutherland. 1997. Global air-sea flux of $\mathrm{CO}_{2}$ : An estimate based on measurements of sea-air $\mathrm{CO}_{2}$ difference. Proceedings of the National Academy of Science 94:8292-99.

TTO (Transient Tracers in the Ocean). 1986a. North Atlantic Study, 1 April - 19 October 1981. Data report SIO No. 86-15, PACODF publication No. 221. Scripps Institution of Oceanography, La Jolla, Calif.

TTO. 1986b. Tropical Atlantic Study, 1 December 1982 - 18 February 1983. Data report SIO No. 86-16, PACODF publication No. 222. Scripps Institution of Oceanography, La Jolla, Calif.

Sabine C. L., R. M. Key, K. M. Johnson, F. J. Millero, A. Poisson, J. L. Sarmiento, D. W. R. Wallace, and C. D. Winn. 1999. Anthropogenic $\mathrm{CO}_{2}$ inventory of the Indian Ocean. Global Biogeochemical Cycles 13(1):179-98.

Sarmiento J. C., J. C. Orr, and U. Siegenthaler. 1992. A perturbation simulation of $\mathrm{CO}_{2}$ uptake in an ocean general circulation model. Journal of Geophysical Research 97:3621-46.

Wallace, D. W. R. 1995. Monitoring global ocean carbon inventories. Ocean Observing System Development panel. Texas A \& M University, College Station, Texas.

Washington, W. M., and G. A. Meehl. 1996. High latitude climate change in a global coupled ocean-atmosphere-sea ice model with increased atmospheric $\mathrm{CO}_{2}$. Journal of Geophysical Research 101(D8):12795-801.

Wessel, P., and W. H. F. Smith. 1995. New version of the generic mapping tools released. EOS Transactions American Geophysical Union 76:329. 


\section{PART 2:}

\section{CONTENT AND FORMAT OF DATA FILES}





\section{FILE DESCRIPTIONS}

This section describes the content and format of each of the 19 files that comprise this numeric data package (NDP) (see Table 2). Because CDIAC distributes the data set in several ways (e.g., via anonymous FTP and on floppy diskette), each of the 19 files is referenced by both an ASCII file name, which is given in lowercase, bold-faced type (e.g., ndp076.txt) and a file number. The remainder of this section describes (or lists, where appropriate) the contents of each file.

Table 2. Content, size, and format of data files

File number, name, and description

\section{Logical} records

1,904

58,117

. ndp076.txt:

a detailed description of the data set, methods

of calculations of carbon fields, the five

FORTRAN 77 data-retrieval routines,

and the thirteen oceanographic data files

2. coef_talk.for:

a FORTRAN 77 data-retrieval routine to read and print coef_talk.dat (File 7)

3. coef_tco2.for:

a FORTRAN 77 data-retrieval routine to read and print coef_tco2.dat (File 8)

4. mld1x1.for:

a FORTRAN 77 data-retrieval routine to read and print mld1x1.dat (File 9)

5. talkdat.for:

a FORTRAN 77 data-retrieval routine to read and print talk_*.dat (Files 10-14)

6. tco2dat.for:

a FORTRAN 77 data-retrieval routine to read and print tco2_*.dat (Files 15-19)

7. coef_talk.dat:

a listing of the $a, b$, and $c$ coefficients used to calculate TALK fields

8. coef_tco2.dat:

a listing of the $a, b, c$, and $d$ coefficients used to calculate $\mathrm{TCO}_{2}$ fields 
Table 2. (continued)

\begin{tabular}{|c|c|c|}
\hline $\begin{array}{l}\text { File number, name, } \\
\text { and description }\end{array}$ & $\begin{array}{l}\text { Logical } \\
\text { records }\end{array}$ & $\begin{array}{l}\text { File size } \\
\text { in bytes }\end{array}$ \\
\hline $\begin{array}{l}\text { 9. mld1x1.dat: } \\
\text { mixed layer depths }\left(1^{\circ} \times 1^{\circ} \text { grid }\right) \text { calculated } \\
\text { for each month of the year }\end{array}$ & 34,144 & $4,574,721$ \\
\hline $\begin{array}{l}\text { 10-14. talk_*.dat: } \\
\text { interpolated TALK fields calculated } \\
\text { annually and for each quarter }\end{array}$ & $4,973,480$ & $447,612,905$ \\
\hline $\begin{array}{l}\text { 15-19. tco2_*dat: } \\
\text { interpolated } \mathrm{TCO}_{2} \text { fields calculated } \\
\text { annually and for each quarter }\end{array}$ & $4,980,110$ & $323,714,083$ \\
\hline Total & $10,085,818$ & $783,466,596$ \\
\hline
\end{tabular}

\section{1 ndp076.txt (File 1)}

This file contains a detailed description of the data set, methods of calculations, the five FORTRAN 77 data-retrieval routines, and the thirteen oceanographic data files. It exists primarily for the benefit of individuals who acquire this database as machine-readable data files from CDIAC.

\section{2 coef_talk.for (File 2)}

This file contains a FORTRAN 77 data-retrieval routine to read and print coef_talk.dat (File 7). The following is a listing of this program. For additional information regarding variable definitions, variable lengths, variable types, units, and codes, please see the description for coef_talk.dat in Sect. 7.7.

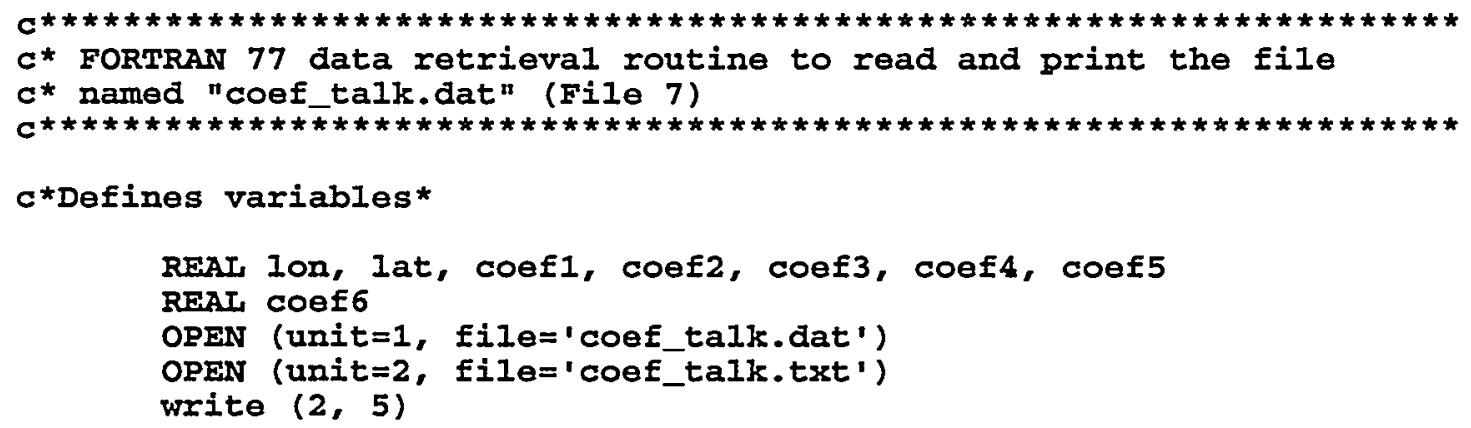




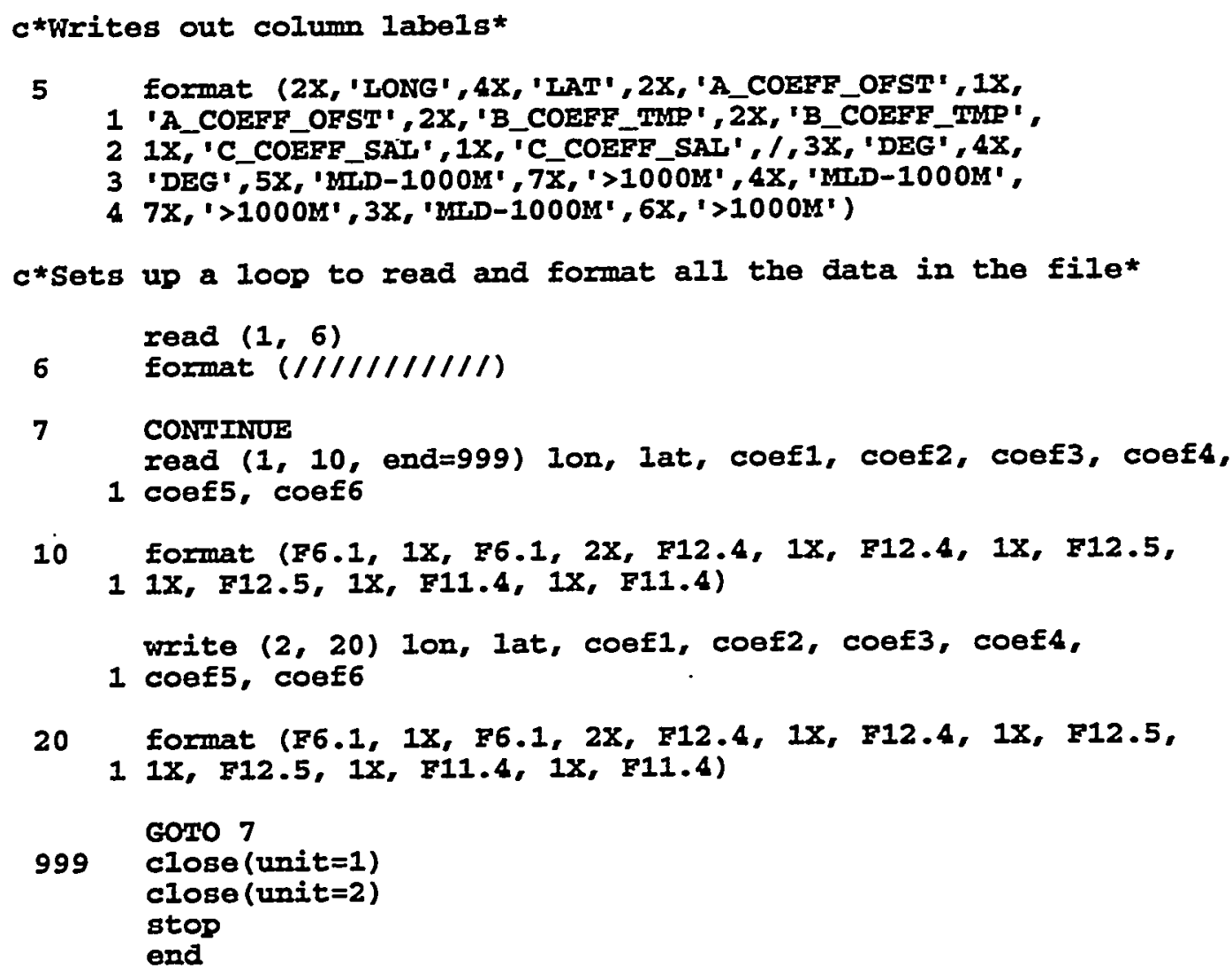

\section{3 coef_tco2.for (File 3)}

This file contains a FORTRAN 77 data-retrieval routine to read and print coef_tco2.dat (File 8). The following is a listing of this program. For additional information regarding variable definitions, variable lengths, variable types, units, and codes, please see the description for coef_tco2.dat in Sect. 7.8.

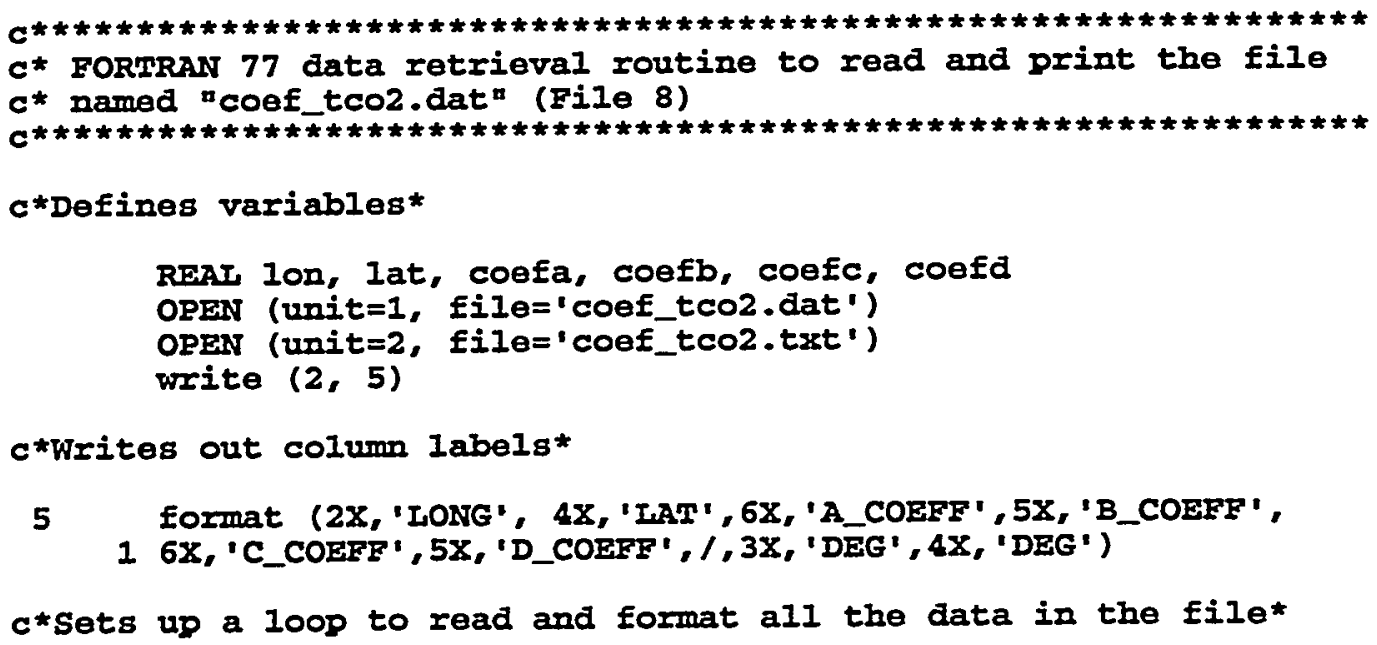




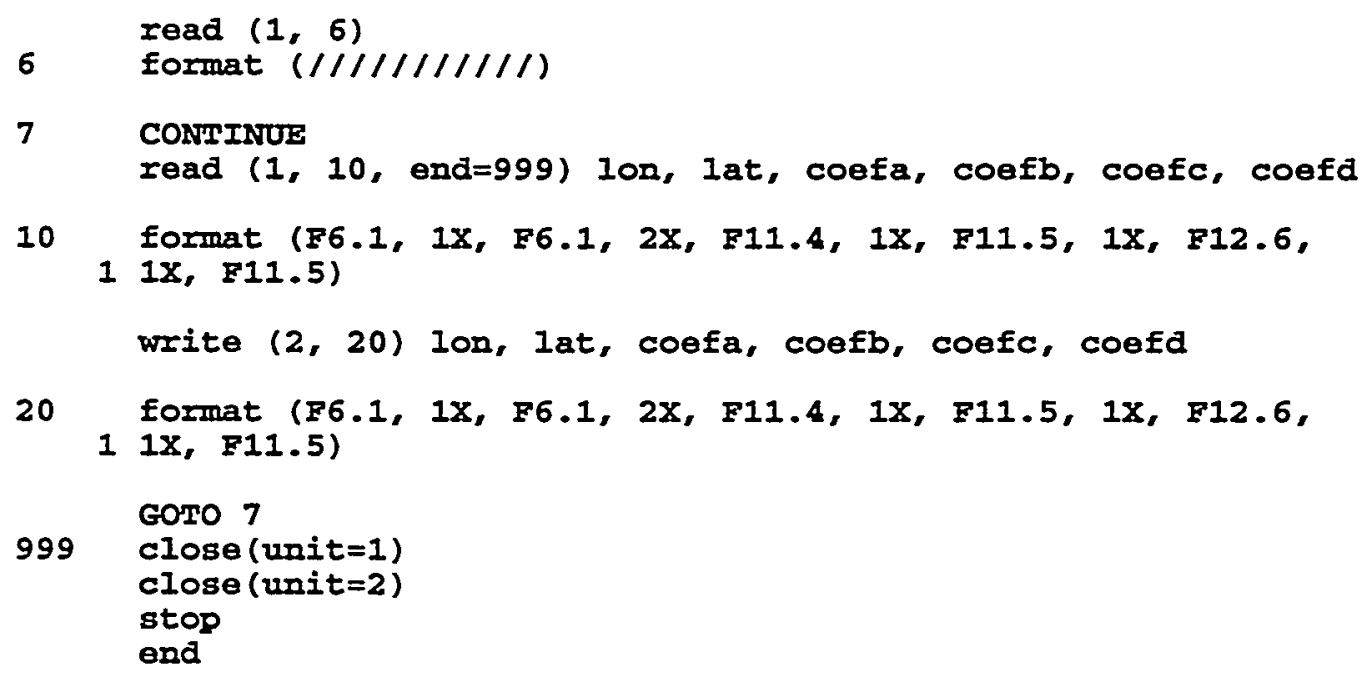

\section{4 mld1x1.for (File 4)}

This file contains a FORTRAN 77 data-retrieval routine to read and print mld1x1.dat (File 9). The following is a listing of this program. For additional information regarding variable definitions, variable lengths, variable types, units, and codes, please see the description for mld1x1.dat in Sect. 7.9.

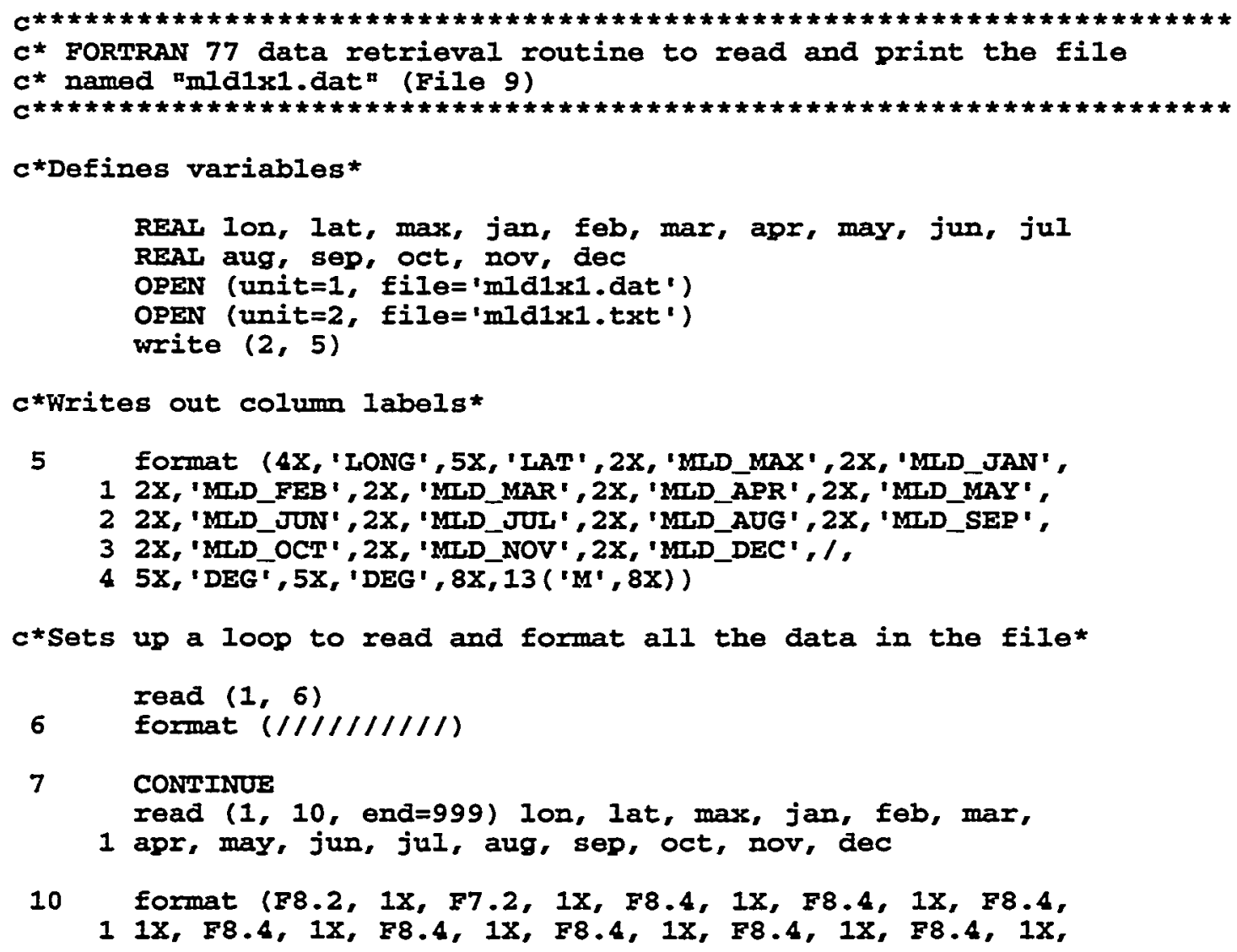


2 F8.4, IX, F8.4, 1X, F8.4, 1X, F8.4, 1X, F8.4)

write $(2,20)$ 1on, lat, max, jan, feb, mar,

1 apr, may, jun, jul, aug, sep, oct, nov, dec

2 F8.4, 1X, F8.4, 1X, F8.4, 1X, F8.4, 1X, F8.4)

GOTO 7

999

close (unit $=1$ )

close (unit $=2$ )

stop

end

\section{5 talkdat.for (File 5)}

This file contains a FORTRAN 77 data-retrieval routine to read and print talk_*.dat (Files 10-14). The following is a listing of this program. For additional information regarding variable definitions, variable lengths, variable types, units, and codes, please see the description for talk_*dat in Sect. 7.10.

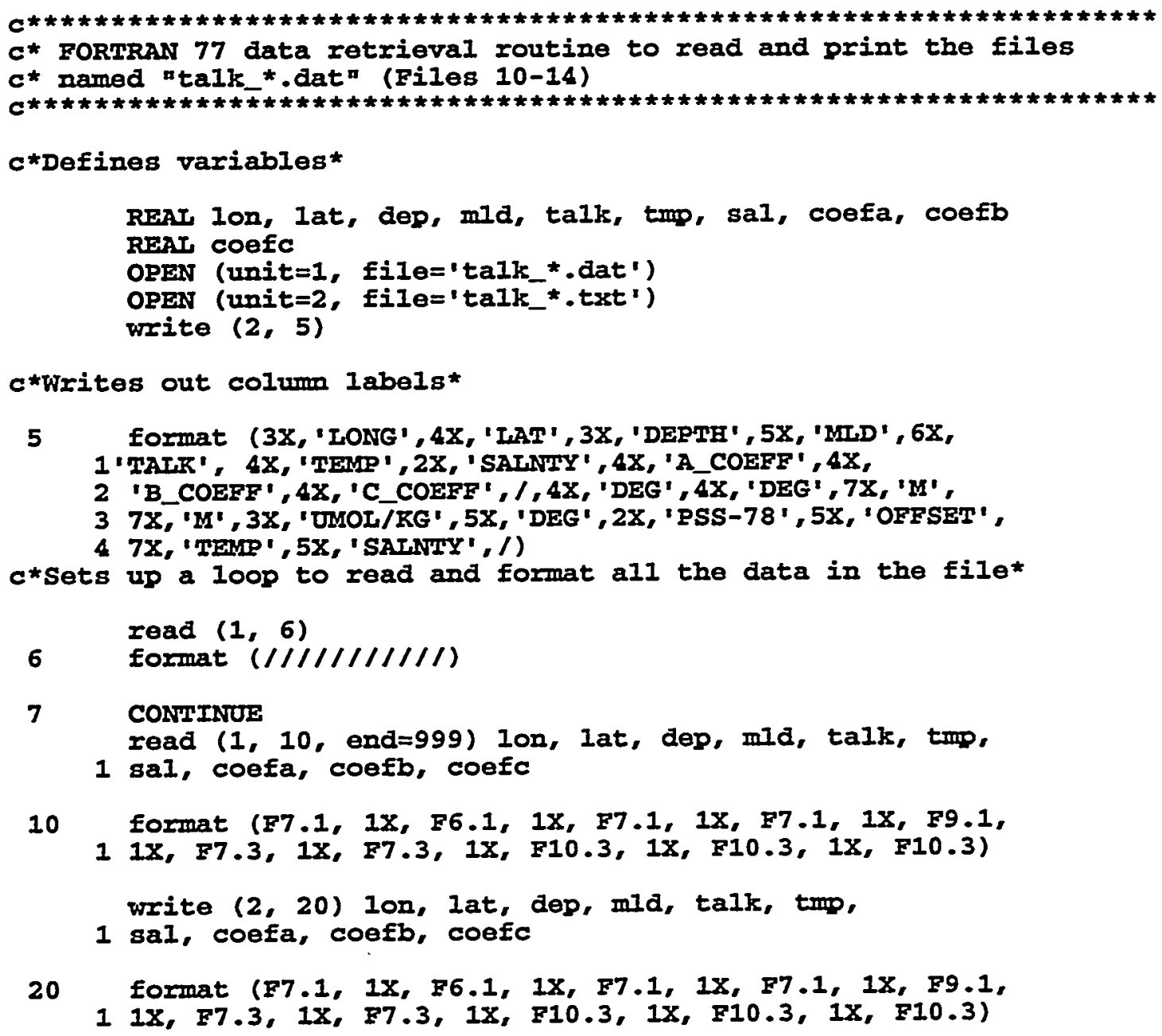


GOTO 7

999 close (unit=1)

close (unit $=2$ )

stop

end

\section{6 tco2dat.for (File 6)}

This file contains a FORTRAN 77 data-retrieval routine to read and print tco2_*.dat (Files 15-19). The following is a listing of this program. For additional information regarding variable definitions, variable lengths, variable types, units, and codes, please see the description for tco2_*.dat in Sect. 7.11.

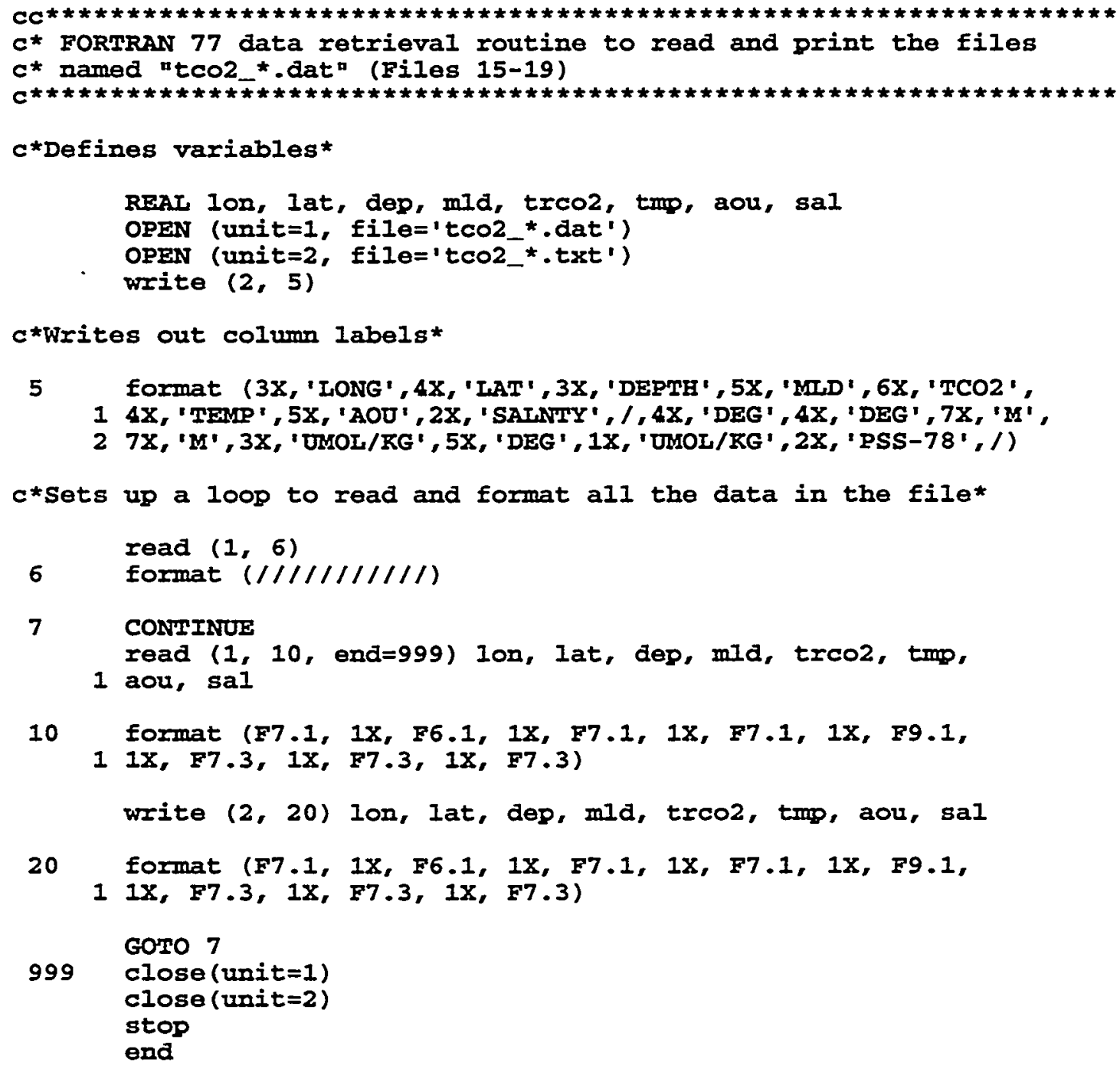




\section{7 coef_talk.dat (File 7)}

This file provides the coefficients $a, b$, and $c$ used to calculate TALK from the potential temperature (T) and salinity (S). Each line of the file contains a longitude, latitude, offset coefficient $a$ (between depths MLD and $1000 \mathrm{~m}$ ), offset coefficient $a$ (below $1000 \mathrm{~m}$ ), T coefficient $b$ (between depths MLD and $1000 \mathrm{~m}$ ), T coefficient $b$ (below $1000 \mathrm{~m}$ ), $\mathrm{S}$ coefficient $c$ (between depths MLD and $1000 \mathrm{~m}$ ), and $\mathrm{S}$ coefficient $c$ (below $1000 \mathrm{~m}$ ). The file is sorted by longitude and latitude and can be read by using the following FORTRAN 77 code (contained in coef_talk.for, File 2):

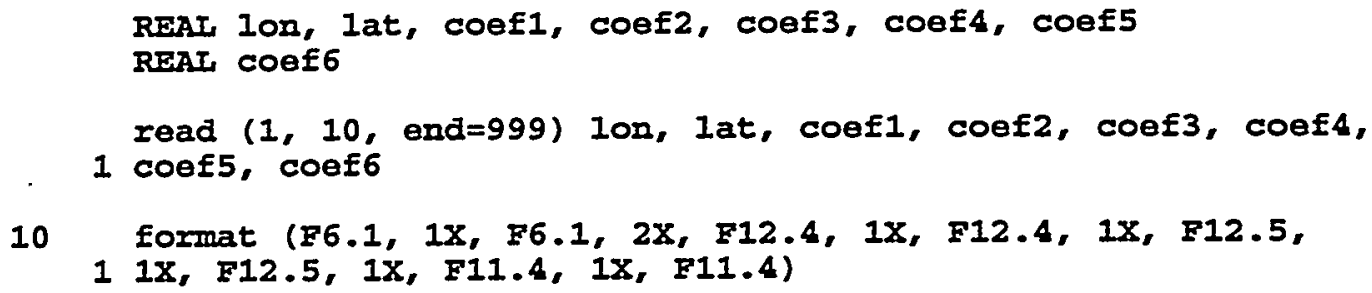

Stated in tabular form, the contents include the following:

\begin{tabular}{llccc}
\hline Variable & $\begin{array}{c}\text { Variable } \\
\text { type }\end{array}$ & $\begin{array}{c}\text { Variable } \\
\text { width }\end{array}$ & $\begin{array}{c}\text { Starting } \\
\text { column }\end{array}$ & $\begin{array}{c}\text { Ending } \\
\text { column }\end{array}$ \\
\hline lon & Numeric & 6 & 1 & 6 \\
lat & Numeric & 6 & 8 & 13 \\
coef1 & Numeric & 12 & 16 & 27 \\
coef2 & Numeric & 12 & 29 & 40 \\
coef3 & Numeric & 12 & 42 & 53 \\
coef4 & Numeric & 12 & 55 & 66 \\
coef5 & Numeric & 11 & 68 & 78 \\
coef6 & Numeric & 11 & 80 & 90 \\
\hline
\end{tabular}

The variables are defined as follows:

$\begin{array}{ll}\text { lon } & \text { is the longitude for which coefficients were calculated; } \\ \text { lat } & \text { is the latitude for which coefficients were calculated; } \\ \text { coef1 } & \text { is the offset coefficient } a \text { (for depths between MLD and } 1000 \mathrm{~m} \text { ); } \\ \text { coef2 } & \text { is the offset coefficient } a \text { (for depths below } 1000 \mathrm{~m} \text { ); } \\ \text { coef3 } & \text { is the T coefficient } b \text { (for depths between MLD and } 1000 \mathrm{~m} \text { ); } \\ \text { coef4 } & \text { is the T coefficient } b \text { (for depths below } 1000 \mathrm{~m} \text { ); } \\ \text { coef5 } & \text { is the } S \text { coefficient } c \text { (for depths between MLD and } 1000 \mathrm{~m} \text { ); and } \\ \text { coef6 } & \text { is the } S \text { coefficient } c \text { (for depths below } 1000 \mathrm{~m} \text { ). }\end{array}$




\section{8 coef_tco2.dat (File 8)}

This file provides the coefficients $a, b, c$, and $d$ used to calculate $\mathrm{TCO}_{2}$ from the T, apparent oxygen utilization (AOU), and S. Each line of the file contains a longitude, latitude, offset coefficient $a$ (below MLD), T coefficient $b$ (below MLD), AOU coefficient $c$ (below $1000 \mathrm{~m}$ ), and $\mathrm{S}$ coefficient $d$ (below MLD). The file is sorted by longitude and latitude and can be read by using the following FORTRAN 77 code (contained in coef_tco2.for, File 3):

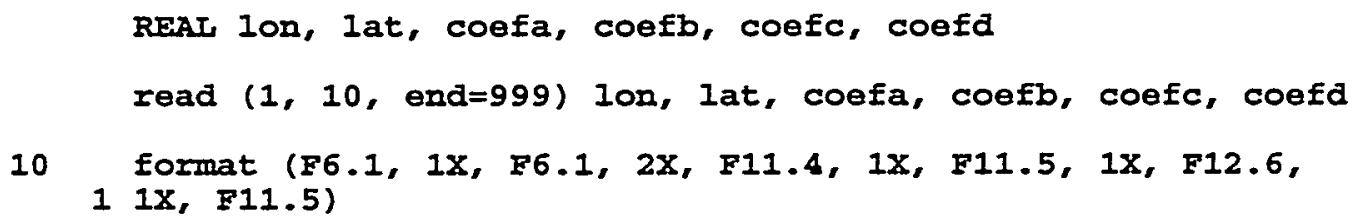

Stated in tabular form, the contents include the following:

\begin{tabular}{llccc}
\hline Variable & $\begin{array}{c}\text { Variable } \\
\text { type }\end{array}$ & $\begin{array}{c}\text { Variable } \\
\text { width }\end{array}$ & $\begin{array}{c}\text { Starting } \\
\text { column }\end{array}$ & $\begin{array}{c}\text { Ending } \\
\text { column }\end{array}$ \\
\hline lon & Numeric & 6 & 1 & 6 \\
lat & Numeric & 6 & 8 & 13 \\
coefa & Numeric & 11 & 16 & 26 \\
coefb & Numeric & 11 & 28 & 38 \\
coefc & Numeric & 12 & 40 & 51 \\
coefd & Numeric & 11 & 53 & 63 \\
\hline
\end{tabular}

The variables are defined as follows:

lon is the longitude for which coefficients were calculated;

lat is the latitude for which coefficients were calculated;

coefa is the offset coefficient $a$ (for depths below MLD);

coefb is the $\mathrm{T}$ coefficient $b$ (for depths below MLD);

coefc is the AOU coefficient $c$ (for depths below MLD; and

coefd is the S coefficient $d$ (for depths below MLD). 


\section{9 mld1x1.dat (File 9)}

This file provides a mixed layer depths $\left(1^{\circ} \times 1^{\circ}\right.$ grid) calculated for each month of the year. The file is sorted by longitude and latitude and can be read by using the following FORTRAN 77 code (contained in mld1x1.for, File 4):

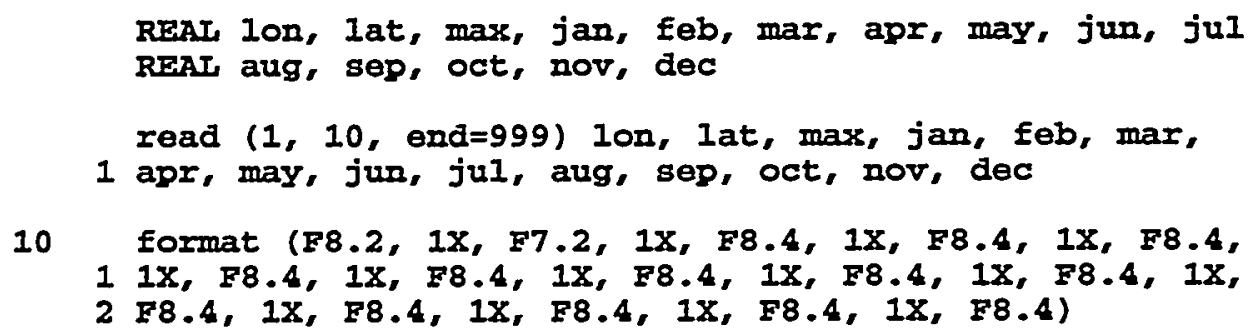

Stated in tabular form, the contents include the following:

\begin{tabular}{llccc}
\hline Variable & $\begin{array}{c}\text { Variable } \\
\text { type }\end{array}$ & $\begin{array}{c}\text { Variable } \\
\text { width }\end{array}$ & $\begin{array}{c}\text { Starting } \\
\text { column }\end{array}$ & $\begin{array}{c}\text { Ending } \\
\text { column }\end{array}$ \\
\hline lon & Numeric & 8 & 1 & 8 \\
lat & Numeric & 7 & 10 & 16 \\
max & Numeric & 8 & 18 & 25 \\
jan & Numeric & 8 & 27 & 34 \\
feb & Numeric & 8 & 36 & 43 \\
mar & Numeric & 8 & 45 & 52 \\
apr & Numeric & 8 & 54 & 61 \\
may & Numeric & 8 & 63 & 70 \\
jun & Numeric & 8 & 72 & 79 \\
jul & Numeric & 8 & 81 & 88 \\
aug & Numeric & 8 & 90 & 97 \\
sep & Numeric & 8 & 99 & 106 \\
oct & Numeric & 8 & 108 & 115 \\
nov & Numeric & 8 & 117 & 124 \\
dec & Numeric & 8 & 126 & 133 \\
& & & & \\
\hline
\end{tabular}

The variables are defined as follows:

lon is the longitude for which MLDs were calculated;

lat is the latitude for which MLDs were calculated;

$\max$ is the year maximum MLD;

jan-dec is the calculated MLD for each month of the year. 


\subsection{0 talk_*.dat (Files 10-14)}

These files provide the interpolated TALK fields calculated annually and for each quarter (talk_ann.dat, talk_djf.dat, talk_mam.dat, talk_jja.dat, and talk_son.dat). The files are sorted by longitude and latitude and can be read by using the following FORTRAN 77 code (contained in talkdat.for, File 5):

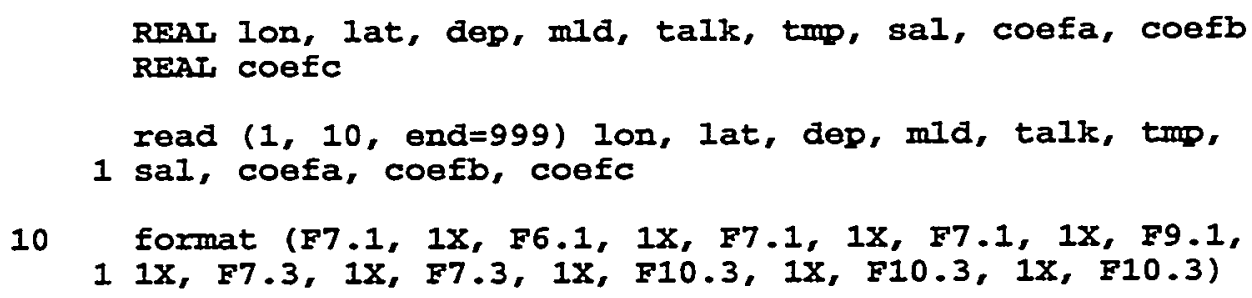

Stated in tabular form, the contents include the following:

\begin{tabular}{llccc}
\hline Variable & $\begin{array}{c}\text { Variable } \\
\text { type }\end{array}$ & $\begin{array}{c}\text { Variable } \\
\text { width }\end{array}$ & $\begin{array}{c}\text { Starting } \\
\text { column }\end{array}$ & $\begin{array}{c}\text { Ending } \\
\text { column }\end{array}$ \\
\hline lon & Numeric & 7 & 1 & 7 \\
lat & Numeric & 6 & 9 & 14 \\
dep & Numeric & 7 & 16 & 22 \\
mld & Numeric & 7 & 24 & 30 \\
talk & Numeric & 9 & 32 & 40 \\
tmp & Numeric & 7 & 42 & 48 \\
sal & Numeric & 7 & 50 & 56 \\
coefa & Numeric & 10 & 58 & 67 \\
coefb & Numeric & 10 & 69 & 78 \\
coefc & Numeric & 10 & 80 & 89 \\
& & & & \\
\hline
\end{tabular}

The variables are defined as follows:

\begin{tabular}{|c|c|}
\hline lon & is the longitude for which TALK was calculated; \\
\hline lat & is the latitude for which TALK was calculated; \\
\hline dep & is the depth for which TALK was calculated (m); \\
\hline mld & is the maximum layer depth $(\mathrm{m})$; \\
\hline talk & is the total alkalinity $(\mu \mathrm{mol} / \mathrm{kg})$; \\
\hline tmp & is the temperature $\left({ }^{\circ} \mathrm{C}\right)$; \\
\hline & is the salinity; \\
\hline
\end{tabular}



coefa is the $a$ coefficient (offset);
coefb is the $b$ coefficient to temperature; and
coefc is the $c$ coefficient to salinity.

\subsection{1 tco2_*.dat (Files 15-19)}

These files provide the interpolated $\mathrm{TCO}_{2}$ fields calculated annually and for each quarter (tco2_ann.dat, tco2_djf.dat, tco2_mam.dat, tco2_jja.dat, and tco2_son.dat). The files are sorted by longitude and latitude and can be read by using the following FORTRAN 77 code (contained in tco2dat.for, File 6):

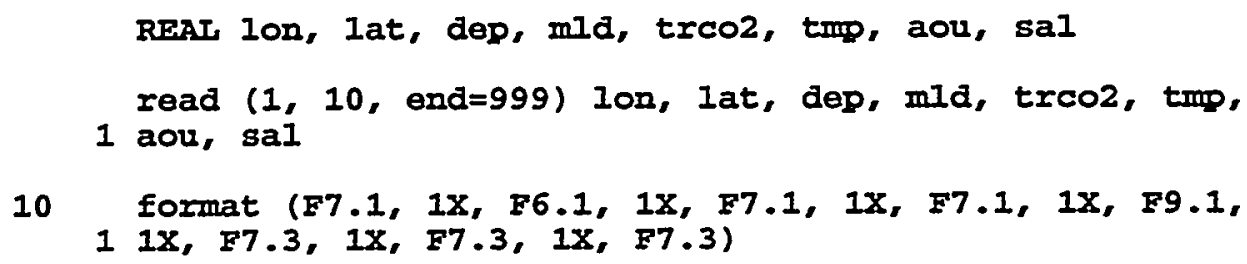

Stated in tabular form, the contents include the following:

\begin{tabular}{llccc}
\hline Variable & $\begin{array}{c}\text { Variable } \\
\text { type }\end{array}$ & $\begin{array}{c}\text { Variable } \\
\text { width }\end{array}$ & $\begin{array}{c}\text { Starting } \\
\text { column }\end{array}$ & $\begin{array}{c}\text { Ending } \\
\text { column }\end{array}$ \\
\hline lon & Numeric & 7 & 1 & 7 \\
lat & Numeric & 6 & 9 & 14 \\
dep & Numeric & 7 & 16 & 22 \\
mld & Numeric & 7 & 24 & 30 \\
tco2 & Numeric & 9 & 32 & 40 \\
tmp & Numeric & 7 & 42 & 48 \\
aou & Numeric & 7 & 50 & 56 \\
sal & Numeric & 7 & 58 & 64 \\
\hline
\end{tabular}

The variables are defined as follows:

Ion
Iat the longitude for which $\mathrm{TCO}_{2}$ was calculated;
is the latitude for which $\mathrm{TCO}_{2}$ was calculated;
is the depth for which $\mathrm{TCO}_{2}$ was calculated $(\mathrm{m})$;
mld
ico2 the maximum layer depth $(\mathrm{m}) ;$
is the total carbon dioxide $(\mu \mathrm{mol} / \mathrm{kg}) ;$




$\begin{array}{ll}\text { tmp } & \text { is the temperature }\left({ }^{\circ} \mathrm{C}\right) ; \\ \text { aou } & \text { is the apparent oxygen utilization }(\mu \mathrm{mol} / \mathrm{kg}) \text {; and } \\ \text { sal } & \text { is the salinity. }\end{array}$




\section{Internal Distribution}

1. T. A. Boden

2. M. D. Burtis

3. R. M. Cushman

4-28. S. B. Jones

29. D. P. Kaiser

30. P. Kanciruk

31. J. M. Loar
32. T. E. Myrick

33. D. E. Shepherd

34. L. D. Voorhees

35. Central Research Library - email only

36-39. ESD Library

40. Laboratory Records Department

\section{External Distribution}

41. J. Afghan, Marine Physical Laboratory, Scripps Institution of Oceanography, 9500 Gilman Drive, La Jolla, CA 92093-0902

42. A. G. Alexiou, UNESCO/IOC, 1 rue Miollis, 75732 Paris Cedex 15, France

43. W. E. Asher, University of Washington, Joint Institute for the Study of the Atmosphere and the Ocean, Box 354235, Seattle, WA 98195

44. N. Bates, Bermuda Biological Station for Research, Ferry Reach GE 01, Bermuda

45. R. Bidigare, University of Hawaii, Department of Oceanography, 1000 Pope Road, Honolulu, HI 96822

46. P. G. Brewer, Monterey Bay Aquarium Research Institute, P.O. Box 628, 7700 Sandholt Road, Moss Landing, CA 95039

47. O. B. Brown, University of Miami, 4500 Rickenbacker Causeway, Miami, FL 33149

48. C. Brunet, Laboratoire de Physique et Chimie Marines, Université Pierre et Marie Curie, 4 place Jussieu, 75252 Paris Cedex 05, France

49. R. H. Byrne, University of South Florida, Department of Marine Science, 140 Seventh Avenue S., St. Petersburg, FL 33701

50. E. G. Cumesty, ORNL Site Manager, Department of Energy, Oak Ridge National Laboratory, P.O. Box 2008, Oak Ridge, TN 37831-6269

51. G. Cutter, Old Dominion University, Department of Oceanography, Norfolk, VA 23529

52. A. G. Dickson, Scripps Institution of Oceanography, University of California, San Diego, Marine Physical Laboratory, 9500 Gilman Drive, La Jolla, CA 92093-0244

53. L. Dilling, NOAA/Office of Global Programs, 1100 Wayne Avenue, Suite 1225, Silver Spring, MD 20910-5603

54. S. Doney, National Center for Atmospheric Research, Oceanography Section, P.O. Box 3000, Boulder, CO 80307

55. H. W. Ducklow, College of William and Mary, Virginia Institute of Marine Sciences, P. O. Box 1346, Gloucester Point, VA 23062

56. J. W. Elwood, Department of Energy, Office of Biological and Environmental Research, Environmental Sciences Division, SC-74, 19901 Germantown Road, Germantown, MD 20874

57. G. Esser, Justus-Liebig-University, Institute for Plant Ecology, Heinrich-Buff-Ring 38, D-35392 Giessen, Germany

58. R. A. Feely, NOAA/PMEL, 7600 Sand Point Way NE, Seattle, WA 98115

59. W. Ferrell, Department of Energy, Office of Biological and Environmental Research, Environmental Sciences Division, SC-74, 19901 Germantown Road, Germantown, MD 20874

60. R. H. Gammon, University of Washington, Chemistry Department, Box 351700, Seattle, WA 98195

61. J.-P. Gattuso, Observatoire Oceanologique Europeen, Avenue Saint-Martin, MC-98000, Monaco

62. J. P. Giesy, Michigan State University, College of Natural Science, Department of Zoology, 203 Natural Science Building, East Lansing, MI 48824-1115 
63. J. Goddard, Columbia University, Lamont-Doherty Earth Observatory, Climate/ Environment/Ocean Division, Rt. 9W, Palisades, NY 10964

64-73. C. M. Goyet, Lawrence Livermore National Laboratory, Climate and Carbon Cycle Modeling Group, L-103, P.O. Box 808, 7000 East Avenue, Livermore, CA 94550

74. N. Gruber, Princeton University, Atmospheric and Oceanic Sciences, 304 A Sayre Hall, Princeton, NJ 08544

75. P. Guenther, Geosciences Research Division 0220, University of California, San Diego, 9500 Gilman Drive, La Jolla, CA 92093-0220

76. D. O. Hall, University of London, Division of Biosphere Sciences, King's College, Campden Hill Road, London W8 7AH, United Kingdom

77. A. Harashima, Japan Environment Agency, Global Environmental Research Division, 16-2 Onogawa, Tsukuba, Ibaraki 305, Japan

78-87. R. J. Healy, Information Systems Associate II, National Ocean Sciences Accelerator Mass Spectrometry Facility, Woods Hole Oceanographic Institution, Woods Hole, MA 02543-1539

88. M. Hein, Freshwater Biological Laboratory, Helsingoersgade 51, DK-3400 Hilleroed, Denmark

89. A. Hittelman, WDC-A for Solid Earth Geophysics, NOAA Code E/GC1, 325 Broadway, Boulder, $\mathrm{CO} 80303$

90. H. Hodgson, British Library, Boston Spa, DSC, Special Acquisitions, Wetherby, West Yorkshire, LS23 7BQ, United Kingdom

91. H. Hong, Xiamen University, Environmental Science Research Center, Post Code 361005, Mail Box 1085, Xiamen, Fujian, Peoples Republic of China

92. C. A. Hood, GCRIO, 2250 Pierce Road, Bay City, MI 48710

93. J. C. Houghton, Department of Energy, Office of Biological and Environmental Research, Environmental Sciences Division, SC-74, 19901 Germantown Road, Germantown, MD 20874

94. H. Y. Inoue, Geochemical Research Department, Meteorological Research Institute, Nagamine 1-1, Tsukuba, Ibaraki 305-0032, Japan

95. M. Ishii, Geochemical Research Department, Meteorological Research Institute, Nagamine 1-1, Tsukuba, Ibaraki 305-0032, Japan

96. T. Johannessen, Centre for Environmental and Resource Studies, Hoeyteknologisenteret, University of Bergen, N-5020 Bergen, Norway

97. F. Joos, University of Bern, Physics Institute, KUP, Sidlerstr. 5, Bern CH-3012, Switzerland

98. D. M. Karl, University of Hawaii, Department of Oceanography, 1000 Pope Road, Honolulu, HI 96822

99. T. R. Karl, National Climatic Data Center, 151 Patton Avenue, Federal Building, Room 516E, Asheville, NC 28801

100. S. Kempe, Schnittspahnstr. 9, D-64287 Darmstadt, Germany

101. R. M. Key, Princeton University, Geology Department, Princeton, NJ 08544

102. K.-R. Kim, Seoul National University, Dept. of Oceanology, Seoul 151-7442, Korea

103. T. Kimoto, Research Institute of Oceano-Chemistry, Osaka Office, 3-1 Fumahashi-cho, Tennoji-ku, Osaka 543, Japan

104. D. Kitzis, Environmental Research Laboratories, NOAA, 325 Broadway, Boulder, CO 80308-3328

105. B. Klein, University Laval, GIROQ, Pav. Vachon, Quebec, PQ, G1K 7P4, Canada

106. J. C. Klink, Miami University, Department of Geography, 217 Shideler Hall, Oxford, OH 45056

107. J. Val Klump, University of Wisconsin, Center for Great Lakes Studies, 600 E. Greenfield Avenue, Milwaukee, WI 53204

108. A. Körtzinger, Institut für Meereskunde, Düsternbroker Weg 20, 24105 Kiel, Germany

109. A. Kozyr, The University of Tennessee, Pellissippi Research Facility, 10521 Research Drive, Suite 100, Knoxville, TN 37932

110. S. Levitus, National Oceanographic Data Center, National Oceanic and Atmospheric Administration, E/OC5, 1315 East West Highway, Room 4362, Silver Spring, MD 20910

111. E. Lewis, Brookhaven National Laboratory, Upton, NY 11973 
112. A. A. Lucier, National Council of the Paper Industry, Air and Stream Improvement, P.O. Box 13318, Research Triangle Park, NC 27709-3318

113. P. Lunn, Department of Energy, Office of Biological and Environmental Research, Environmental Sciences Division, SC-74, 19901 Germantown Road, Germantown, MD 20874

114. T. H. Mace, U.S. Environmental Protection Agency, National Exposure Research Laboratory, Environmental Sciences Divison/ORD, P.O. Box 93478, Las Vegas, NV 89193-3478

115. J. J. McCarthy, Harvard University, Museum of Comparative Zoology, 26 Oxford Street, Cambridge, MA 02138

116. M. C. MacCracken, National Assessment Coordination Office, Suite 750, 400 Virginia Avenue, Washington, DC 20024

117. L. Merlivat, LODYC, Université Pierre et Marie Curie, 4 place Jussieu, 75252 Paris Cedex 05, France

118. N. Metzl, Universite Pierre et Marie Curie, Laboratoire de Physique et Chimie Marines, T 24-25-Case 134, 4 place Jussieu, 75252 Paris Cedex 05, France

119. F. J. Millero, University of Miami, RSMAS, 4600 Rickenbacker Causeway, Miami, FL 33149

120. L. Mintrop, Abteilung Meereschemie, Institut für Meereskunde, Düsternbrooker Weg 20, D-24105 Kiel, Germany

121. J. W. Morse, Texas A\&M University, Department of Oceanography, College Station, TX 77843

122. R. E. Munn, University of Toronto, Institute for Environmental Studies, Haultain Building, 170 College Street, Toronto, Ontario M5S 1A4, Canada

123. S. Murayama, National Institute for Resources and Environment, Environmental Assessment Department, 16-3 Onogawa, Tsukuba, Ibaraki 305, Japan

124. P. P. Murphy, National Oceanographic Data Center, National Oceanic and Atmospheric Administration, E/OC5, 1315 East West Highway, Room 4362, Silver Spring, MD 20910

125. National Oceanic and Atmospheric Administration, Central Library, 1315 East-West Highway, 2nd Floor, SSMC 3, Silver Spring, MD 20910

126. S. Nishioka, National Institute for Environmental Studies, Global Environment Research Division, 16-2 Onogawa, Tsukuba, Ibaraki 305, Japan

127. Y. Nojiri, National Institute for Environmental Studies, Tsukuba, Ibaraki 305-0053, Japan

128. J. R. Oh, Korea Ocean Research and Development Institute, Chemical Oceanography Division, An San P.O. Box 29, Seoul 4325-600, Korea

129. J. Olafsson, Marine Research Institute, P.O. Box 1390, Skulagata 4, 121 Reykjavik, Iceland

130. E. Ohtaki, Environmental Science and Technology, Okayama University, Tsushima-Naka 2-1-1, Okayama 700, Japan

131. C. Oudot, Centre ORSTOM de Cayenne, B.P. 165-97323, Cayene Cedex, Guyana

132. A. C. Palmisano, Department of Energy, Office of Biological and Environmental Research, Environmental Sciences Division, SC-74, 19901 Germantown Road, Germantown, MD 20874

133. B. Parra, Department of Energy, Office of Biological and Environmental Research, Environmental Sciences Division, SC-74, 19901 Germantown Road, Germantown, MD 20874

134. A. Patrinos, Department of Energy, Office of Biological and Environmental Research, Environmental Sciences Division, SC-74, 19901 Germantown Road, Germantown, MD 20874

135. T.-H. Peng, NOAA/AOML, Ocean Chemistry Division, 4301 Rickenbacker Causeway, Miami, FL 33149

136. A. Poisson, Laboratoire de Physique et Chimi Marines, Université Pierre et Marie Curie, 4 place Jussieu, 75252 Paris Cedex 05, France

137. D. B. Preselin, University of California, Department of Biological Sciences, Santa Barbara, CA 93106

138. P. D. Quay, University of Washington, School of Oceanography, Box 357940, Seattle, WA 98195

139. R. Y. Rand, USDA, Global Change Data and Information Management, 10301 Baltimore

Boulevard, Beltsville, MD 20705 
140. J. L. Reid, Scripps Institution of Oceanography, University of California San Diego, M/C 0230, 9500 Gilman Drive, La Jolla, CA 92093-0230

141. J. Ribbe, University of Washington, Joint Institute for the Study of the Atmosphere and Oceans, Box \# 35425, Seattle, WA 98195

142. M. R. Riches, Department of Energy, Office of Biological and Environmental Research, Environmental Sciences Division, SC-74, 19901 Germantown Road, Germantown, MD 20874

143. M. F. Roberts, Pacific Marine Environmental Laboratory, National Oceanic and Atmospheric Administration, 7600 Sand Point Way NE, Seattle, WA 98115

144. L. Robinson, Director, Environmental Sciences Institute, Florida A\&M University, Science Research Facility, 1520 S. Bronough Street, Tallahassee, FL 32307

145. S. Rubin, YSI, Inc., 1700/1725 Brannum Lane, Yellow Springs, OH 45387

146-155. J. Ryan, Monterey Bay, Aquarium Research Institute, P.O. Box 628, 7700 Sandholdt Road, Moss Landing, CA 95039-0628

156. C. L. Sabine, Pacific Marine Environmental Laboratory, National Oceanic and Atmospheric Administration, 7600 Sand Point Way NE, Seattle, WA 98115

157. M. M. Sarin, Physical Research Laboratory, Navrangpura, Ahmedabad 380009, India

158. J. L. Sarmiento, Princeton University, Atmospheric and Oceanic Sciences Program, P.O. Box CN710, Sayre Hall, Princeton, NJ 08544

159. B. Schneider, Baltic Sea Research Institute, Seestrase 15, Warnmunde, D-18 119, Germany

160. K. Shitashima, Central Research Institute of Electric Power Industry, Marine Science Group, 1646 Abiko, Abiko-city, Chiba, 270-11, Japan

161. N. Silva, Universidad Catolica de Valparaiso, Escuela de Ciencias de Mar, Casilla 1020, Valparaiso, Chile

162. M. H. C. Stoll, Netherlands Institute for Sea Research (NIOZ), Dept. MCG, P. O. Box 59, 1790 AB Den Burg-Texel, The Netherlands

163. E. T. Sundquist, U.S. Geological Survey, Quissett Campus, Branch of Atlantic Marine Geology, Woods Hole, MA 02543

164. S. C. Sutherland, Columbia University, Lamont-Doherty Earth Observatory, P.O. Box 1000, U.S. Route 9W, Palisades, NY 10964

165. J. H. Swift, Scripps Institution of Oceanography, University of California, San Diego Oceanographic Data Facility, 9500 Gilman Drive, La Jolla, CA 92093-0124

166. T. Takahashi, Columbia University, Lamont-Doherty Earth Observatory, Climate/Environment/Ocean Division, Rt. 9W, Palisades, NY 10964

167. L. Talley, Scripps Institution of Oceanography, University of California San Diego, M/C 0230, 9500 Gilman Drive, La Jolla, CA 92093-0230

168. P. Tans, Climate Monitoring and Diagnostics Laboratory, NOAA, 325 Broadway, Boulder, CO 80308-3328

169. J. A. Taylor, Australian National University, CRES, GPO Box 4, Canberra, ACT 0200, Australia

170. J. M. Tiedje, 540 Plant and Soil Sciences Building, Michigan State University, East Lansing, Michigan 48824

171. B. Tilbrook, CSIRO Division of Marine Research, P.O. Box 1538, Hobart TAS 7001, Australia

172. J. R. G. Townshend, University of Maryland, Dept. of Geography, 1113 Lefrak Hall College Park, MD 20742

173. J. Tucker, Marine Biological Laboratory, Woods Hole, MA 02543

174. D. Turner, University of Goteborg, Department of Analytical and Marine Chemistry, S-41296 Goteborg, Sweden

175. D. W. R. Wallace, Abteilung Meereschemie, Institut für Meereskunde, Düsternbrooker Weg 20, D-24105 Kiel, Germany

176. R. H. Wanninkhof, NOAA/AOML/OCD, 4301 Rickenbacker Causeway, Miami, FL 33149

177. A. J. Watson, School of Environmental Sciences, University of East Anglia, Norwich NR4 7TJ, United Kingdom 
178. F. Webster, University of Delaware, College of Marine Studies, Lewes, DE 19958

179. R. F. Weiss, Scripps Institution of Oceanography, University of California, Mail Code A-020, Room 2271, Ritter Hall, La Jolla, CA 92093

180. C. Winn, Associate Professor and Director of Marine Science, Hawaii Pacific University, 45-045 Kamehameha Hwy., Kaneohe, HI 96744-6297

181. C. S. Wong, Government of Canada, Institute of Ocean Sciences, P.O. Box 6000, 9860 West Saanich Road, Sidney, BC V8L 4B2, Canada

182. L. Xu, Xiamen University, Environmental Science Research Center, Xiamen, Fujian, Peoples Republic of China

183. E. Yakushev, Shirshov Institute of Oceanology, 23 Krasikova, Moscow 117218, Russia

184. E. Yamashita, Research Institute of Technology, Okayama University, Ridaicho 1-1, Okayama 700, Japan

185. Y. Yosuoka, National Institute for Environmental Studies, Center Global Environment Research, 16-2 Onogawa, Tsukuba, Ibaraki 305, Japan

186. Database Section, National Institute for Environmental Studies, Center for Global Environmental Research, 16-2 Onogawa, Tsukuba, Ibaraki 305, Japan

187. Energy Library (HR-832.2/WAS), Department of Energy, Office of Administration and Management, GA-138 Forrestal Building, Washington, DC 20585

188. Energy Library (HR-832.1/GTN), Department of Energy, Office of Administration and Management, G-034, Washington, DC 20585

189-190. Office of Scientific and Technical Information, P. O. Box 62, Oak Ridge, TN 37831 